Historic, Archive Document

Do not assume content reflects current scientific knowledge, policies, or practices. 

ESTABLISHED 1852.

W. E. ROSSNEY,

PRESIDENT.
SIDNEY TUTTLE,

VICE-PRESIDENT.
INCORPORATED 1890.

GEO. J. FOSTER, SECRETARY.

\section{FALL OF 1899.}

\section{WHOLESALE CATALOGUE}

NUMBER 2.

82ND EDITION. ...OF...

Trees, Plants, Shrubs, Roses, Bulbs, Greenhouse and Bedding Plants, Etc.

OF THE

Phoenix Nursery Company $+1$

SUCCESSORS TO SIDNEY TUTTLE \& CO.

PROPRIETORS

BloOMington Phoenix Nursery

BLOOMINGTON, ILLINOIS.

P. O. EOX 625.

OFFICE AND \REENHOUSES:

1215 NORTA PARK ST.

Electric cars pass the Office between B1omingtor and Norma1 erery twenty minutes.

office During the packing Season-At the Packing and Nursery Grounds at Normal, three blocks southeast of Normal Iassenger Depot, or two blocks south of terminus of Bloomington and Norma1 Electric Stret Railvay.

OLD AND NEW TE.EPHONES NO. 119.

600 ACRES.

13 GREENHOUSES. 
TN presenting our Wholesale Price-List for the fall of 1899 , we wish to thank all our patrons for past favors, and solicit a careful consideration of our very low prices and the completeness of our assortment of Nursery and Greenhouse Stock

A11 orders receised by us have our pærsonal aid prompt attention, and we guarantee reasonable satisfaction in every case as thousands of unsolicited testimonials now on file fully attest.

We are prepared to offer special indicements to Nurserymen and Dealers buying in large quantities.

With our large storage cellars and packing houses, and a complete system of water works, distributing water to all parts of our packing grounds, we feel that our facilities for the careful and proper handlins of Nursery stock are not excelled by any nursery establishment in the country.

Our shipping facilities are unexceled. Bloomington being an important railroad center we are able to forward prompt1s to all sections. With the I1linois Centra1 R. R., Chicago \& A1ton R. R., Lake Erie \& Western R. R., and the C. C. C. \& St. L. R. R. (Big Four), and their branches, we hare direct communication with Chicago, St. Louis, Cincinnati, Kansas City, Indianapolis, Dubuque, Cairo, and Lafayette, by daily freight trains without transfer. On account of our unusual facilities we a re also enabled to obtain very low freight rates to all points. We ship with flattering results to Australia, Mexico, New Zealand, Nova Scotia, Oregon, Washington, California, Maine, and a11 the other states in the Union.

We exercise great care to have all articlestrue to name.

PHOENIX NURSERY COMPANY.

\section{TERMS AND CONDITIONS.}

Terms of Payment.-Cash or satsfactory security, before shipnient of stock. A11 orders to be sent by Express, "C. 0. D." must be accompanied by ONE-HALF THE AMOUN'T IN CASH.

Remit by Posta1 or Express Money Orders.Bank Drafts on New York, Chicago, or St. Louis, payable to order of PHOENIX NURSERY COMPANY, or currency by express prepaid.

Orders and Conditions of Sale.-Please order EARLY, with order legible and separate from body of the letter, with lame of Pistoffice, County, and State, and how you wish package directed on the ORDER.

Long specified lists are subjectto specialprices. Needed specifications as to age size, style, etc., state on the order, t) save the trouble of referring to previous corres, pondence.

On all wholesale bills, the choce of varieties must be left to us. Particular varie ties named in order furnished as fa: as practcable. Orders forbidding substitution we fill so far only as we can supply tht sorts specified.

Prices.--Prices herein a re net and strictlylimited to the Fa11 of 1899 . Where items are quoted by the thousand, five hu1dred willbe furnished at thousand rates.

Packing.-Prices do not includepacking. Packing carefu11y done in boxes, most1y sometimes in bales or parcels, for which we clarge moderately; for 1arge boxes, 8 or 9 feet by $2 \frac{1}{2}$, three of which usually kold 1,000 5to 6 feet apple- $\$ 2.50 \mathrm{each}$, and in proportion for larger or smaller boxes. NJ CHARCE FOR DELIVERING AT RAILROAD, EXPRESS, OR POSTOFFICE HEEE. On bts by mail, postage and packing extra. Trees per car load, when loaded in julk in bx cars, no additional charge for loading and packing in car. When flat cars are usedand boarded up we charge for additiona 1 labor, 1umber, and material used.

Shipping.-We usua11y commencs shippirg in the Fa11 about October 1.

We prefer parties ordering should indicae the route by which they wish stock sent. In the absence of particular directions, we foward to the best of our judgment; but in no case do we assume any responsib.lit $\mathrm{y}$ afte consignment to purchaser, unless for our own mistakes. When losses occur by detenton en route, claims should be made on the carriers immediately.

It is our custom, when sufficient time is giren, to obtain through Freight or Express Rates on a11 Shipments.

To our customers at a distance we woul also state that the postal rate on Trees and Plants has been reduced from 16 cents to 8 ents per pound, and can be shipped in any number of four pound packages to one addess. We ship a great many root grafts, seedlings, cions, greenhouse plants, $\epsilon$ tc., in ths way.

19 Direct all letters to PHOENIX NURSRY COMPANY, P. O. BOX 625, BLOOMINGTON, ILIINOIS. 


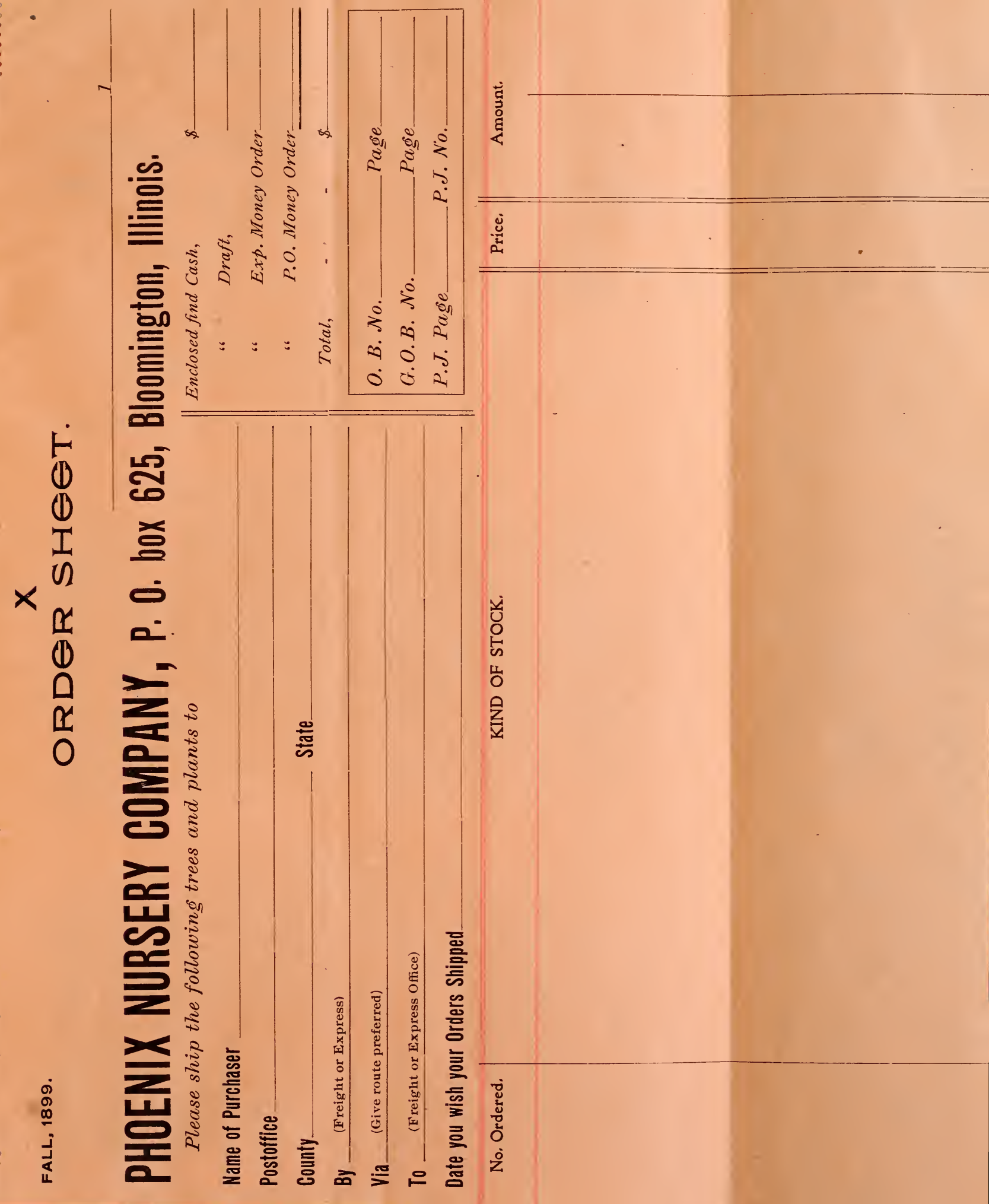





\section{FRUIT TREES.}

For complete list of varieties, with description, see Genera1 Descriptive Catalogue. Except mentioned, prices are for first-class stock.

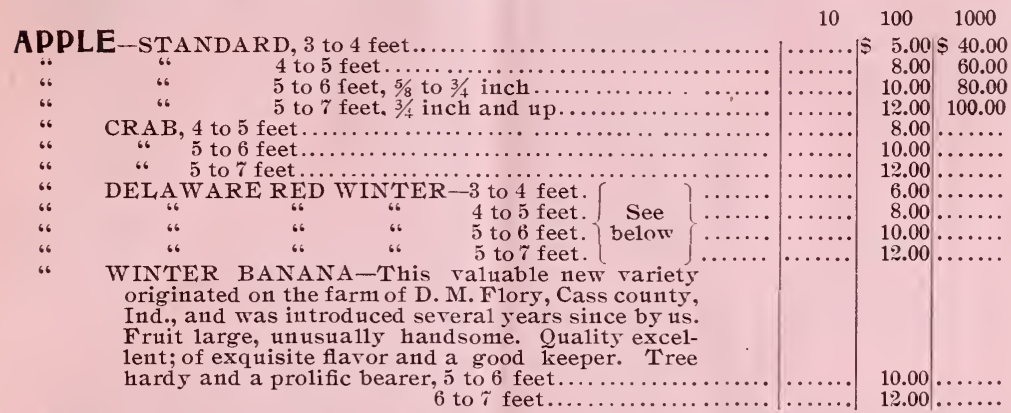

402 We have a fine lot of extra size apple. prices on application.

\section{Leading Sorts of Standard Apple Trees.}

Summer-Astrachan Red, Benoni, Duchess of O1deıburg, Ear1y Harrest, Early Pen . nock, Fourth of Ju1y, Golden Sweet, Horse Apple, Keswick Codlin, Red June, Sops of Wine, Sweet June, Yellow May, Yellow Transparent, Tetofsky (Russian Crab), etc.

Autumn-Strawberry, Buckingham or Fa11 Quee1, Bailey Sweet, Colvert, Fa11 Orange, Fall Stripe, Fameuse, Flora Be11, Haas (Queen), Maiden Blush, Rambo, Ramsdell's Sweet, Sweet Pear, Twenty Ounce, Wealthy, White Hoss, etc.

Winter-Aiken, Arkansas Black, Baldwin, Belleflower Yellow, Ben Daris, Carthouse (Litt1e Romanite), Carpenter's Horse, English Golden Russett, Fulton, Grimes' Golden Pippin, Isham Sweet, Janet or Janeton, Jonathan, King of Tompkins County, Lawver, Limber Twig, Mammoth Blacktwig, Mann, Mo. Superior, Milam, Missouri Pippin, New York Pippin (Ben Davis or Baltimore Red), Newtown Pippin, Northern Spy, Northwestern Greening, Perry Russett, Pewaukee, Plumb's Cider, Price's Sweet, Rock Pippin, Rome Beauty, Smith's Cider, Salome, Ta1man Sweet, Utter's Large Red, White Winter Pearmain, Wolf River, Wagoner, Walbridge, Westfield Seek-No-Further, Willow Twig, Wine Sap, etc.

Crab-Hyslop, Transcendent, Red Siberian, Yellow Siberian, Golden, Genera1 Grant, Whitney's No. 20. White Arctic, Gideon's No. 4, Quaker Beauty, Martha, F1orence, etc.

\section{Delaware Red Winter Apple.}

This variety is now fruiting in this section of the State, and it is with much pleasure that we again call attention to it, and trust it will become justly popular in a11 parts of the country; except, perhaps in the extreme north, where it may not prove sufficient1y hardy to withstand their severe winters. Mr. P. H. Storm, the veteran horticulturist and fruit grower, says of it:

"Having had about fifty years experience in the cultivation of fruit, particularly apples, I have no hesitation in saying the DELAWARE WINTER heads the list. It is a vigorous grower as well as a prolific bearer. It also possesses excellent cooking qualities. Last, but not least, its keeping qualities are far beyond anything else of which I have any knowledge.

"I have eaten them the last of August, ten months after they were gathered. No special care had been taken in their preservation. I have known them exposed to climatic influences through the spring and summer, and yet they were well preserved.

"They are attractive in appearance, being highly colored, red ali over, of large and uniform size. It is without doubt the coming winter apple, for both North and South, as it supplies a long-felt need to both nurserymen and consumers." 


\section{FRUIT TREES-Continued.}

PEAR-STANDARD, extra quality, 5 to 7 feet. Leading Va-

\begin{tabular}{|c|c|c|c|c|c|}
\hline & & 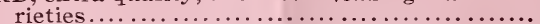 & & $\$ 12.00$ & $\$ 110,00$ \\
\hline 66 & 66 & 1st quality, 4 to $6 \mathrm{ft}$. Leading Varieties......... & & 10.00 & 90.00 \\
\hline "“ & "6 & medium grade, 3 to $4 \mathrm{ft}$. Branched............. & & 8.00 & \\
\hline "6 & "6 & KEIFFER'S HYBRID, ex.qual. 8 to $10 \mathrm{ft}$....... & & 10.00 & \\
\hline " & "6 & "6 1st. " 5 to $7 \mathrm{ft}$....... & & 18.00 & \\
\hline "6 & "6 & " $\quad$ " $3 \mathrm{ft} .1$ year........... & & 10.00 & \\
\hline "6 & "6 & $\begin{array}{l}\text { LONGWORTH'S No. } 1,6 \text { to } 8 \mathrm{ft} \text {, bear- } \\
\text { ing size. (See description below)....... }\end{array}$ & & 50.00 & \\
\hline "6 & "، & $\begin{array}{l}\text { LONGWOR'TH'S No. } 1,5 \text { to } 7 \mathrm{ft} \text {. flirst- } \\
\text { class } \ldots \ldots \ldots \ldots \ldots \ldots \ldots \ldots \ldots \ldots \ldots \ldots \ldots \ldots \ldots \ldots \ldots \ldots \ldots \ldots \ldots\end{array}$ & & 20.00 & \\
\hline ". & "6 & LONGWOR'TH'S No. 1,4 to $6 \mathrm{ft} \ldots \ldots \ldots \ldots \ldots$ & & 15.00 & \\
\hline & & $\begin{array}{l}\text { ROSSNEY (See description below) } 5 \text { to } \\
7 \mathrm{ft}, 2 \text { vears, first-class ...................... }\end{array}$ & & 50.00 & \\
\hline & & ze, 3 years. 1 eading varieties...... & & 10.00 & 75.0 \\
\hline & & & & 8.00 & 60.0 \\
\hline
\end{tabular}

We also have a fine stock of bearing size, Standard and Dwarf Pears of many of the leading varieties. Prices given on application.

The Following are Our Leading Sorts of pears:

Summer-BARTLET'T, CLAPP'S FAVORITE, DOYENNE D'ETE, GOODALE, PETITE MARGUERITE, LECON'TE. OSBAND'S SUMMER, TYSON, ETC., ETC.

Fall-BELLE LUCRATIVE, BEURRE D'ANJOU, BEURRE CLAIRGEAU, BUFFUM, DOYENNE BOUSSOCK, DUCHESS D'ANGOULEME, popular dwarf; FLEMISH BEAUTY, mostly standard; HOWELL, LAWSON, ONONDAGA, L. B. DE JERSEY, popular dwarf; IDAHO, KEIFFER'S HYBRID (large stock, standard and dwarf), SECKLE, SHELDON, WASHINGTON, VERMONT BEAUTY, ETC.

Winter-BEURRE BOSC, LAWRENCE, MT. VERNON, VICAR OR LECURE, ETC.

\section{ROSSNEY PEAR.}

The best and handsomest pear yet produced. Hardy and productire. Ripens two weeks after Bartlett. Strong grower. Luther Burbank. the most noted horticulturist of the age, says under date of October 5. 1895: "The samples of Rossney Pear arrived in due season. The large size. handsome form, and creamy yellow skin with crimson blush gives the fruit a tempting appearance; and the tender. creamy flesh, of just the right texture, with no hard spots and an unusually small core, with its superior fiavor. makes it about the best pear so far seen. If the tree is vigorous, healthy and productive, would prefer it to any other, even the stamdards, Bartlett or Seckel." This is the first time this pear has been offered to the public, and is sent out under our seal and trademark. See price above.

\section{LONGWORTH'S NO. I PEAR.}

\section{The Pear for the Northwest-Every Tree Has Our Seal Attached.}

This is a very hardy Seedling Pear of recent introduction; originated at Dubuque, Iowa, and was grown from seed some forty years since by the veteran nurseryman and horticnlturist. Wim. Longworth. The tree is a strong, upright grower, entirely FREE FROM BLIGHT, and an enormous bearer. Fruit, medium to large, nearly round; skin yellow with warm blush on the sunny side; flesh rather coarse, juicy, sugary, good fiavor. Ripens from first to middle of September.

Having thoroughly tested this variety, we have no hesitancy in recommending it to the public for general planting. This pear has withstood our severest winters without the slightest injury, while other varieties were frozen to the ground. Being free from blight and $\mathbf{E X}$. TREMELY' HARDY, it is a very desirable variety, and should be planted largely. See sizes and prices above.

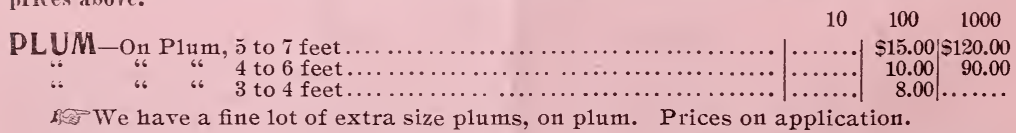

Varieties-ABUNDANCE, BRA DSHAW, BOTAN, BUNKER HILL, BURBANK, CHABOT, DESOTO, FOREST GARDEN, GERMA N PRUNE, GOLDEN, HA WKEYE, JEFFERSON, IMPERIAL GAGE, GEUII, LOMBARD, MINER, MARIANA, PRUNUS SIMONI, POTTAWATTOMIE, QUACKENBOSS, ROLLINGSTONE, REINE CLAUDE, ROBINSON, RED EGG, RED JUNE, SATSUMA, SHIPPER'S PRIDE, SMITH'S ORLEANS, UNION PURPLE. WASHINGTON, WEAVER, WILLARD. WICKSON, WILD GOOSE, WOLF, YELLOW EGG, ETC.

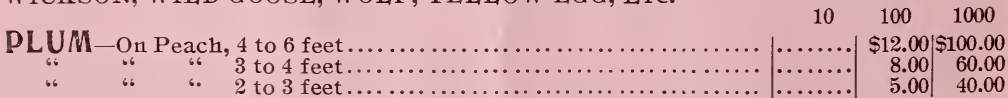

Varieties-ABUNDANCE, BURBANK, BOTAN, BLACKMAN, CHABOT, CHENEY, DE SOTO, FOREST GARDEN, GERMAN PRUNE, GOLDEN, MILTON, MARIANA, OGON, PRUNUS SIMONI, REED, RED JUNE, RICHLAND, SHROPSHIRE DAMSON, WAYLAND, UNDERHILL, WICKSON, WILLARD, WILD GOOSE, WOLF, ETC. 


\section{FRUIT TREES-Continued.}

CHEDPY -

\begin{tabular}{|c|c|c|c|c|}
\hline & . & & & \\
\hline & 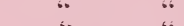 & 5 to $\tilde{i}$ feet, 3 years, 1 inch and up....... & & 15.00 \\
\hline & $\ddot{\circ}$ & 4 to 6 feet, 2 years, 34 inch and up....... & & 15.00 \\
\hline & $" 6$ & 4 to 5 feet, 2 years, $5 / 8$ to $3 / 4 \ldots \ldots \ldots \ldots$ & & 12.00 \\
\hline & "6 & 3 to 4 feet, 2 years..................... & & \\
\hline & SSORTED, 4 & 4 to 6 feet, 2 years, $3 / 4$ inch and up. & & 15.00 \\
\hline & $\because$ & to 5 teet. 2 years, $8 / 8$ to $3 / 1$ inch.... & & 8.00 \\
\hline & NEW WONDEI & 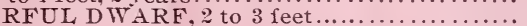 & & 18.00 \\
\hline
\end{tabular}

\section{Leading Sorts of Cherry:}

Sour Varieties-Ear1y Richmond, English Morello, May Duke, Belle de Choisey, Reine Hortense, Montmorencr, Nelson's Kentish, Rora1 Duke, Oliret, Belle Magnifique, Late Duke, Wragg, Northwest, Louis Phillippe, Ostheim, Dye House, etc.

Sweet Varieties-Black Tatarian, Gov. Wood, Yellow Spanish, Rockport Bigarreau, Early Purple Guigne, Windsor, Napoleon Bigarreau, Luelling, etc.

for We have an unusually fine lot of Early Richmond Cherry. 5 to $\tilde{\imath}$ and 4 to 6 feet, and will make speciallow prices on them in large lots.

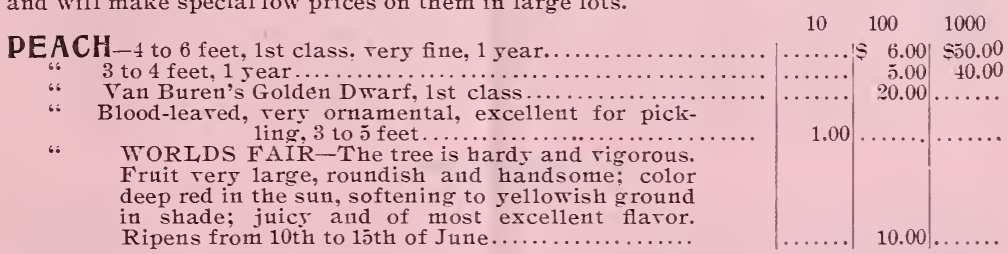

\section{Leading Sorts of Peaches From Our Lists:}

Amsden, Alexander, Bergen's Yellow, Baldwin's Late, Bokara No. 3. Bowers' Ear1y, Bilyeu's Late, Capt. Eade, China Cling. Champion. Cooledge, Crosby. Downing, Early Beatrice, Early Barnard, Ear1y Crawford, Early Rirers, Early York. Early Canada, E1berta, Fitzgerald, Foster. George Fourth. Globe, Greensboro, Gor. Garland, Hales Early, Heath Cling. Heath Free, Honeywe11, Hills Chili, Honest John. Indian Blood Cling, Jacques Rareripe, Late Crawford, La Grange, Lemon Cling. Mt. Rose, Muir, Morris White, O1d Mixon Cling, O1d Mixon Free, Poplar, Picquet's Late, Reere's Farorite, Stump the World, Salway, Steadler, Sneed, Snow, Susquehanna, Smock Free, Triumph, Troth's Early, Thurber, Ward's Late. Waterloo, Washington Cling, Winter King, Wheatland, Wager, Wonderfu1, Yenshi, Ye1low A1berge, etc. etc.

APRICOT_Russian and European, 4 to 6 feet $\ldots \ldots \ldots \ldots \ldots \ldots \ldots \ldots \ldots \ldots \ldots \ldots \ldots \ldots$ 3 to 4 feet............................. 12.00

Tarieties of Apricots; Breda. Ear1y Golden, Moorpark and Royal.

Russian rarieties: Alexis. Alexander, Catherine, Gibb, Budd, and Nicholas.

NECT ARINES-4 10 feet 6 .

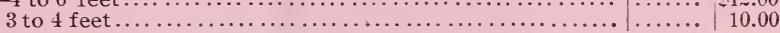

Varieties of Nectarines: E1ruge, Hunt's Tawney, Pitmaston Orange, Stanwick, Early Violet.

\section{MISCELLANEOUS.}

$10 \quad 100$

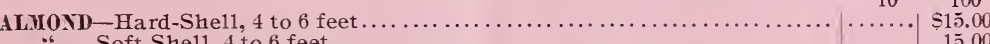

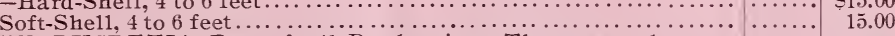

DEWBERRI-LUCRETIA, Best of all Dewberries. The most ra1uable small fruit introduced in many years, 1 year.............. 2.00

JTNEBERRY-DWARF. Shad Bush. Edible fruit, 2 to 3 feet....................

ILLBERRY-Downing's Every bearing, 4 to 6 feet ........................... 20.00

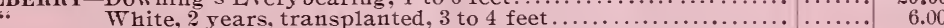

"6 $\quad 4$ to 6 feet................................ 8.00

". Russian, seedlings, 1 year, first-class, per $1,000, \$ 3.00 \ldots \ldots \ldots \ldots \ldots \ldots \ldots \ldots . . .75$

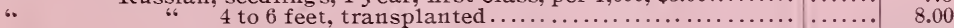

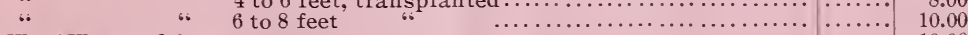

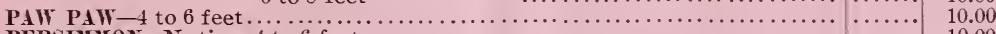

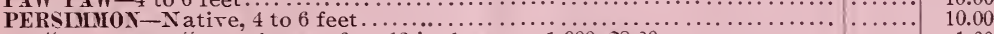

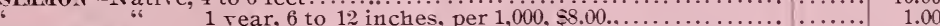

HICKLEBERRY - 2 to 3 feet, we11 known, hardy and productire..................... 4.00

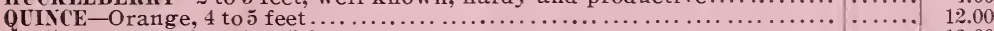

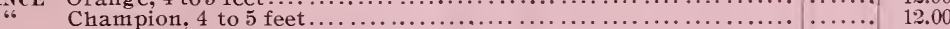

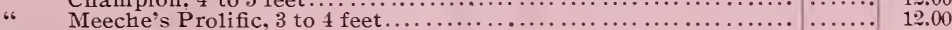

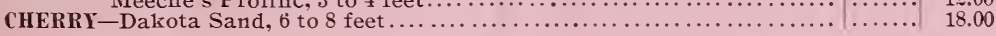




\section{CURRANTS.}

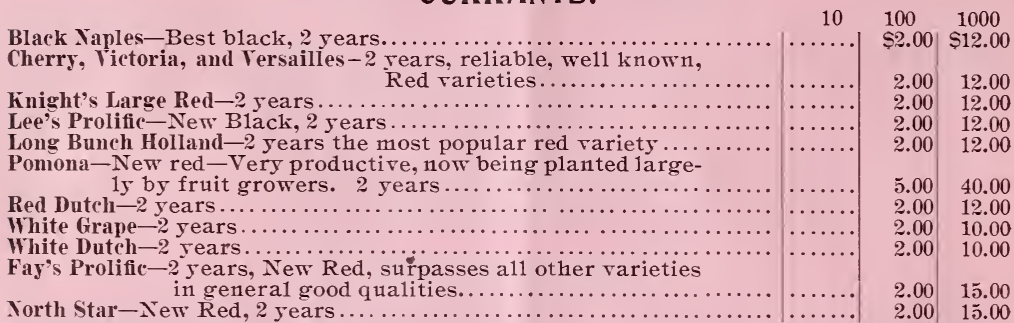

\section{GO0SEBERRIES.}

Magnificent stock of strong young plants.

10

Downing's Seedling-2 years-Strong plants

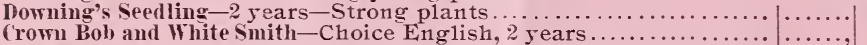

(iuster-2 years.

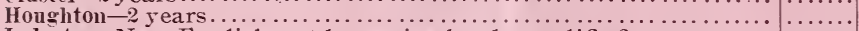

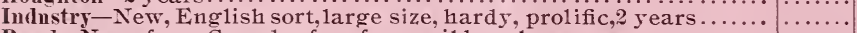

Pearl-New, from Canada, free from mildew, large, very pro-

lific. Strong grower ..........................................

Red Jacket-The best A mericall red rariety yet produced. Fruit

large and of good quality, free from mildew, 2 years............

$100 \quad 1000$

$\$ 3.00 \$ 25.00$

$12.00 \ldots \ldots$.

3.0020 .00

$2.00 \quad 15.00$

$12.00 \ldots \ldots$

$6.00 \ldots \ldots$

$8.00 \ldots \ldots$

\section{BLACKBERRIES.}

\begin{tabular}{|c|c|c|c|}
\hline & & & \\
\hline Kittatimu, grown from root cuttings & 10 & $\begin{array}{l}100 \\
51.50\end{array}$ & $\begin{array}{l}1000 \\
59.00\end{array}$ \\
\hline eedham's white...................... & & 2.00 & \\
\hline awton, grown from root cuttings $\ldots \ldots \ldots \ldots \ldots \ldots \ldots \ldots \ldots \ldots$ & & 2.00 & 12.00 \\
\hline hmer-New. Five points which recommend this berry: Hardy & & & \\
\hline late, large, productive, and of the finest flavor........ & & 3.00 & \\
\hline $\begin{array}{l}\text { Suyder-The Berry of the West. Strong grower, very hardy, } \\
\text { very productive. Never fails to bear a full crop; seren }\end{array}$ & & & \\
\hline $\begin{array}{c}\text { acres yielded } 43,000 \text { quarts. First class } \ldots \ldots \ldots \ldots \ldots \\
\text { Early Harrest, grown from cuttings } \ldots \ldots \ldots \ldots \ldots \ldots \ldots\end{array}$ & & 1.50 & \\
\hline Early Harrest, grown from cuttings............. & & 2.00 & 9.00 \\
\hline Taylor's Prolific, grown from root cuttings..... & & 2.00 & 12.00 \\
\hline ot cuttings........... & & 2.00 & 12.00 \\
\hline one's Hardy. grown from root cuttings.. & & 2.00 & 12.00 \\
\hline ry productive & & 3.00 & \\
\hline D & & 3.00 & \\
\hline
\end{tabular}

\section{DEWBERRIES.}

Lacretia Dewherry-Best of a11. Per 100, \$2.00; per 1000, $\$ 10.00$.

\section{STRAWBERRIES.}

Beder Wood-Most productive. Considered the very best ear1y variety........
Ruby-Strong healthy plant; 1arge staminate blossom; uniform1y productive; fruit of largest size; dark red color clear through; firm enough to shipwe11; a fine keeper after being picked; bears a full crop first.

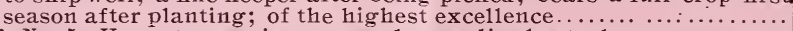

Bubach's Yo. 5-Very strong, vigorous, and exceedingly stocky ..............

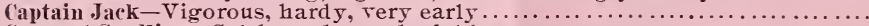

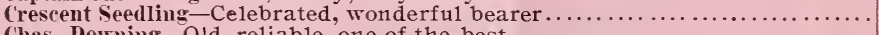

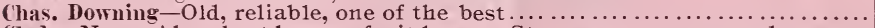

Clyde-New. Abundant bearer, fruit large. Strong grower, succeeds every-

Haviland Seedling-Said to be the earliest 1 iarge berry yet produced $\ldots \ldots \ldots \ldots$

Jessie-From Wisconsin. It has no defects worth naming $\ldots \ldots \ldots \ldots \ldots \ldots$

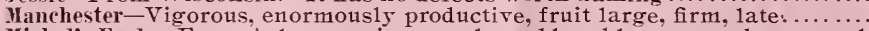

Michel's Early - From A rkansas; is an early and late bloomer, and an exce1-

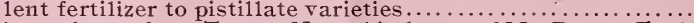

Parker Earle-A new berry from Texas. Named in honor of Mr. Parker Earle. Fruit large, uniformly regular. Flowers perfect. Vigorous grower, massive stools...

$100 \quad 1000$

$\$ 0.75 \$ 4.00$

1.00

7.50

3.50

4.00

3.50

3.50

$1.00 \quad 7.50$

$.75 \quad 4.00$

$75 \quad 4.00$

.\% 4.00

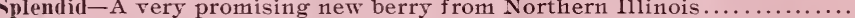

Sharpless Seedling-Largest, most prod uctive of all strawberries..............
Timbrell-Beries large to very large, dark crimson. Very firm, good ship-

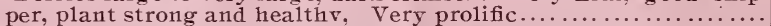

Warfield's Yo. 2-Most highly esteemed for its large, uniform size and good shipping qualities.

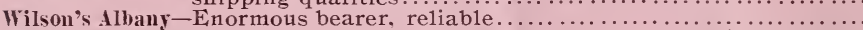

Wolrerton-From Canada. One of the best. Berries large. Fine grower, foliage very vigorous and free from blemish. A pollenizer of

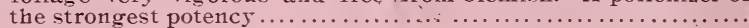

\subsection{0}

3.50

4.00 


\section{RASPBERRIES.}

Cuthbert-One of the best, most profitable berries for genera1 planting; upright, very hardy, prolific; fruit brilliant red, juicy, excellent quality.

Columbian - New-Deep purplish red. sweet and highis fla rored; extra strong canes, wonderfu11y productire. Berro large canes, wonderfull y

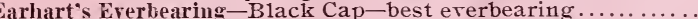

Early 0hio-New Black Cap $\ldots \ldots \ldots \ldots \ldots \ldots \ldots \ldots \ldots \ldots \ldots \ldots \ldots \ldots \ldots$
(irego-RELIABLE, hardy, the rery largest and most pro-

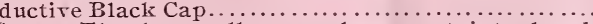

Golden Queen-The best yellow raspherry yet introduced; rigorous, hardy, and remarkably productive; upright.

Hilborn-New, Black Cap, superior qualits, fruit large; very hard $y$; originated in Canada........................... larger than the Gregg. Very vigorous and produc-

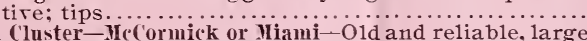

Mammoth Cluster- Mc(ormick or Miami-OOd and reliable, large Black Cap, tips..........................

Yemeha-New, Black Cap, rery hard 5 , ripens with Gregg and

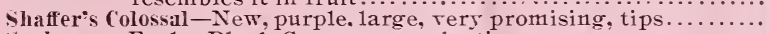

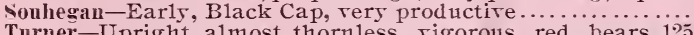

Turner-Upright, almost thornless, rigorous, red, bears 125

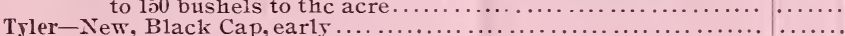

\section{GRAPES.}

Augnst Giant-2 years.

Amber Queen-2 years.

.

Brighton-2 years; hardy, prod uctive, exquisite flaror, resem-

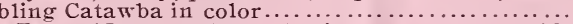

Campbell's Early-New, hardy and rigorous, very prolific berry large, flaror rich and sweet. Flesh firm, but

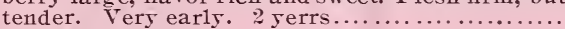

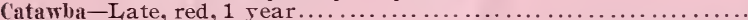
10

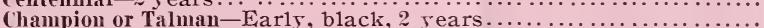

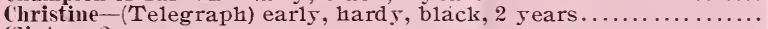

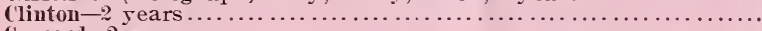

Concord-2 years.

Cottage-Seedling of Concord. Sweeter and earlier 2 years.........

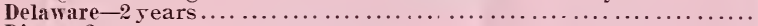

Diana -2 years...

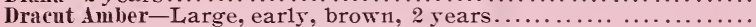

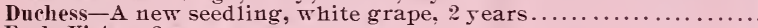

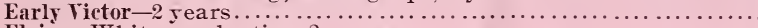

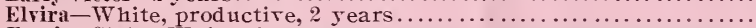

Empire State-White, 2 years...................................
Eaton-A large, showy, black grape; ripens before Concord,

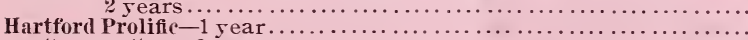

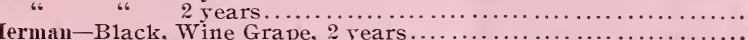

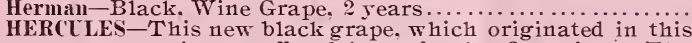
county, is now offered by us for the first time. The rine is a strong, healthy grower, hardy and productive; bunch large, long and broad; berries unusually large and round; a shade darker than Worden and covered with a blue bloom; ripens with Concord. The fruit of this rariety was exhibited at the World's Fair, 1893, by the New York Experimental Station, where it

ILIINOIS EIRI $\mathbf{I}-\mathbf{A}$ new grape which originated with the late G. A. Ensenberger, of this city, some ten years ago. The vine is rery hards, strong grower. Fruit large, purplish black; ripens with Moore's Early. Berry adheres well to the stem, and we beliere will make an

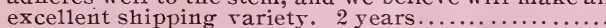

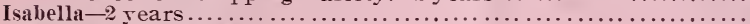

Ires' Seedling-Early, 2 years . . . . . . . . . . . . . . . . . . . . . . Janesville-Vers early, hard $y$, productive, 2 years.

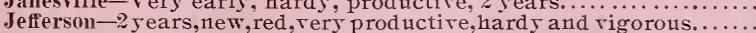

Lady Washington-Vine'hard 5 , berries deep 5 ellow, juic 5 and sweet, 2 years

$4.00 \quad 30.00$

$6.00 \ldots . .$.

$3.00 \quad 25.00$

$3.00 \quad 25.00$

$4.00 \ldots \ldots$.

$6.00 \ldots \ldots$

$7.00 \ldots \ldots$

$6.00 \ldots \ldots$

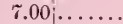

15.00

$4.00 \quad 25.00$

$9.00 \ldots .$.

12.00

$4.00 \ldots \ldots$

$5.00 \ldots \ldots$

12.00 


\section{GRAPES-Continued.}

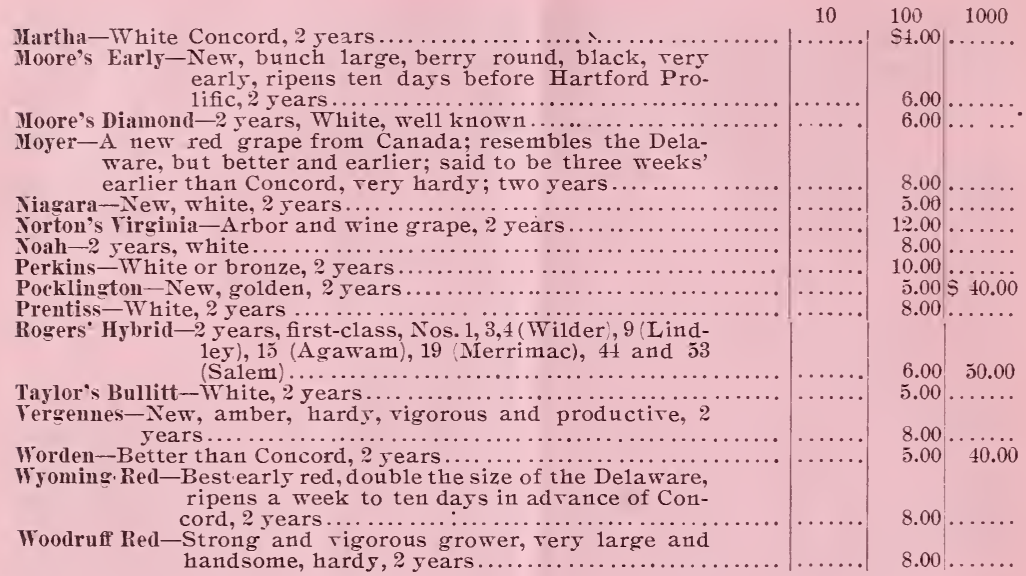

\section{GARDEN ROOTS}

Asparagus-Conorer's Colossa1, 2 years, first-class; per $10.000, \$ 36.00 \ldots . .$.

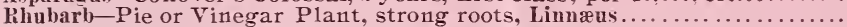

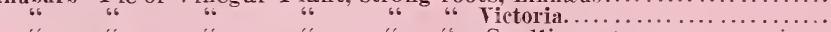

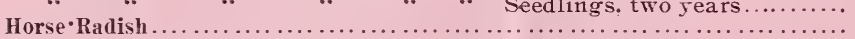

\section{STOCKS, HEDGE PLANTS, CUTTINGS, ETC.}

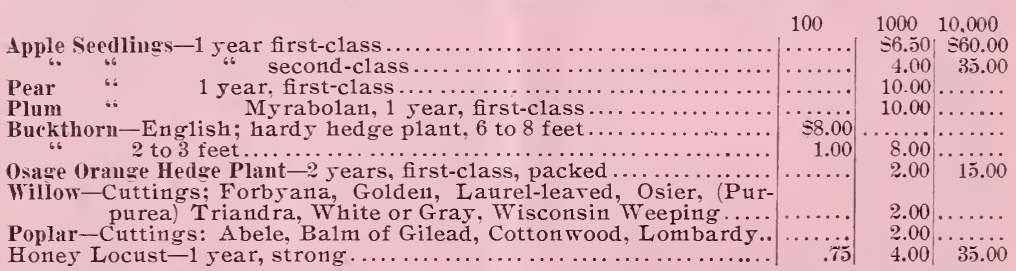

\section{R00T GRAFTS-[Order Early.]}

Largest stock and assortment in the Lnited States.

\section{Our Season for Making Root Grafts Closes March 1.}

Root Grafts are ('ions and Roots grafted and tied together, ready for planting in 11 ursery rows. Orders for special lists of sorts 19 PLEASE SEND EARLY, with one-fourth cash with order, balance before shipment. This is rery important to secure best grafts and your selection of sorts, as we take special pains in cutting and putting up coins fur ear1y orders. Please don't forget this. No extra charge for packing. Eren J0's or 100's of each sort will be put up at the following prices. For smaller or broken lists, prices will be giren on application.

\section{PRICES INCLUDE PACKING.}

\begin{tabular}{|c|c|c|c|c|}
\hline & 100 & 500 & 1000 & 10.000 \\
\hline Apple-Price of assortment & $\$ 1.00$ & $\$ 3.00$ & $\$ 5.00$ & $\$ 45.00$ \\
\hline On whole roots. Pri & 1.50 & 4.00 & 6.50 & 60.00 \\
\hline : Delaware Red Winter. & 1.00 & 4.00 & 6.00 & \\
\hline $\operatorname{ar}-\mathrm{On} w$ & 2.00 & 7.00 & 12.00 & \\
\hline
\end{tabular}

ne - We not recommend the planting of Prune, P1um, and Cherry root grafts. They succeed best from buds. 


\section{EVERGREENS.}

All Vursery Grown, Transplanted, and Root Pruned.

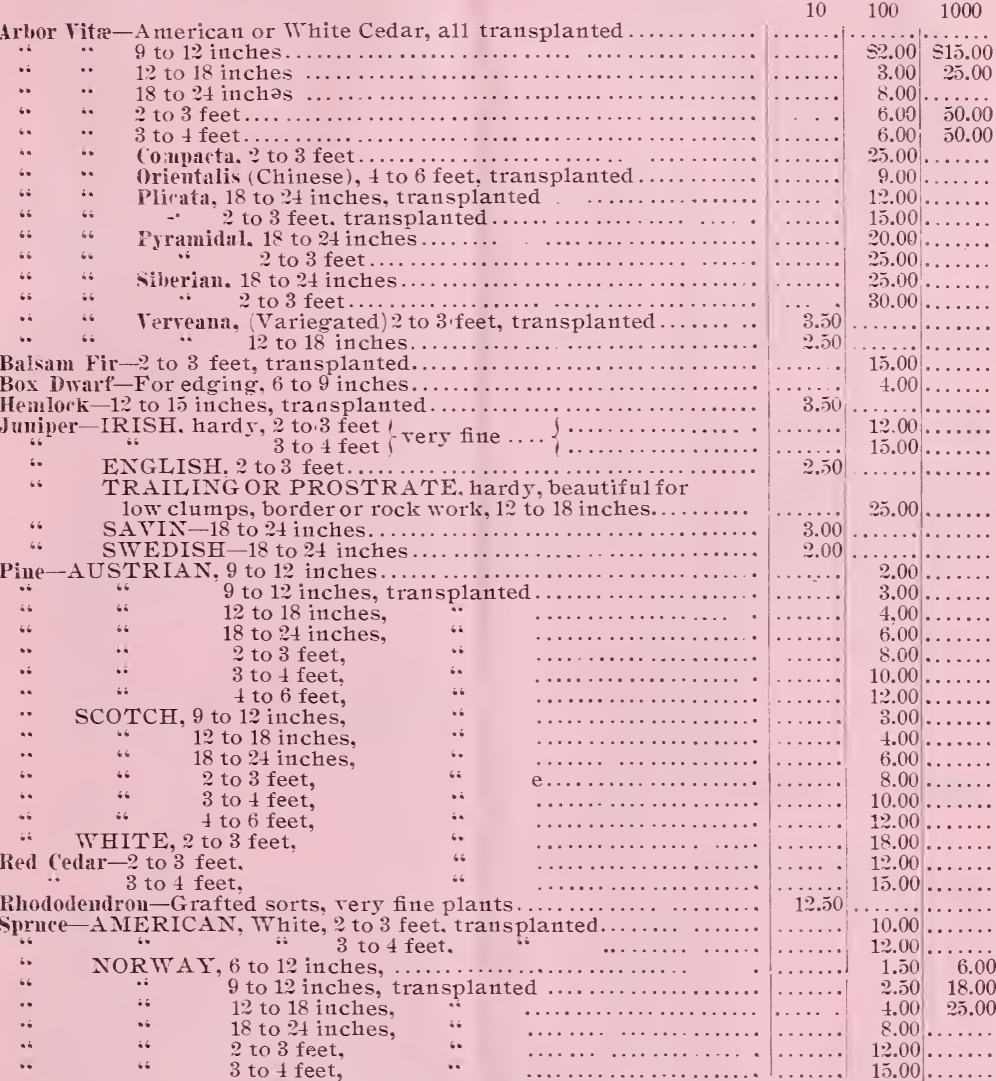

\section{ORNAMENTAL TREES.}

A11 Nursery-grown. For planting and shipping, we usually shorten in rery tall tops.

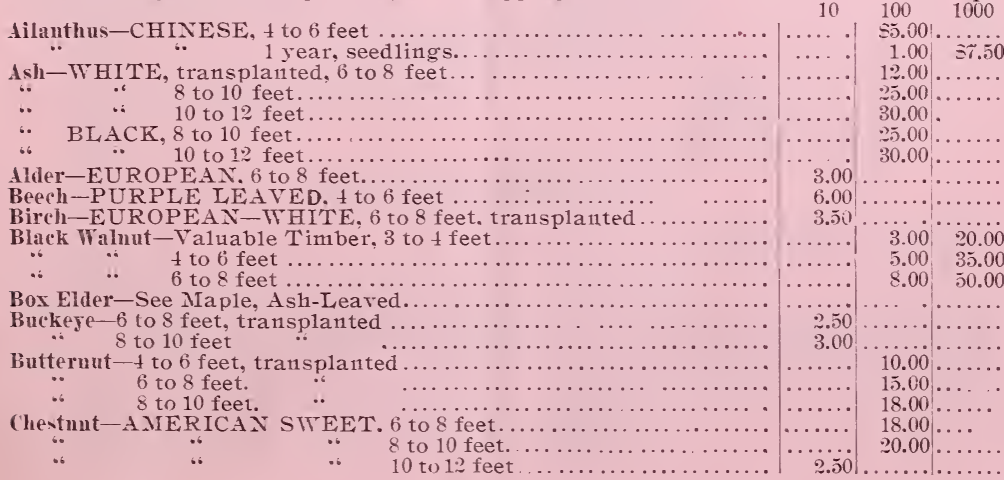




\section{ORNAMENTAL TREES-Continued}

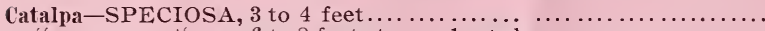
6

6 to 8 feet, transplanted

6 $\quad 6 \quad 8$ to 10 feet,

12 to 12 feet,

14 to 16 feet,

"6 JAPAN, 8 to 10 feet,

6
66
66
66

Cottonwood -4 to 6 feet, transplanted. 6 to 8 feet,

8 to 10 feet,

Cherry-WILD BLACK, 4 to 6 feet

Elm-WHITE, 4 to 6 feet, transplanted

"6 $\quad$ 6. 8 to 8 feet,

6. $\quad$ "6 $\quad 10$ to 12 feet,

SCOTCH, 12 to 14 feet

English Walnut-3 to 4 feet.

Hackberry-Superb shade, 6 to 8 feet.

$$
66 \text {-Superb shade, } 8 \text { to } 10 \text { feet. }
$$

Hickory Shellbark-2 to 3 feet

$$
10 \text { to } 12 \text { feet }
$$

Hop Tree-Shrubby Trefoil, 3 to 4 feet,

$$
4 \text { to } 6 \text { feet, }
$$

Horse Chestnut-5 to 6 feet, transplanted ..

Judas Tree-or RED BUD, 4 to 6 feet

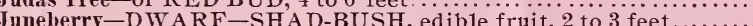

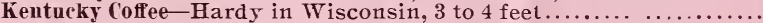
4 to 6 feet

Larch-EUROPEAN, 3 to 4 feet, transplanted

"6 4 to 6 feet,

Linden-A MERICAN, 8 to 8 feet,

66
66
66
66
66
66

$$
\text { 66 } \quad 12 \text { to } 12 \text { feet, }
$$

14 to 16 feet,

16 to 18 feet,

$21 / 2$ inch stem

$2 \mathrm{r} / 2$ to 3 inch stem.

Broad-leaved, 4 to 6 feet.

Magnolia-ACUMINATA, 5 to 6 feet.

6 to 8 feet.
8 to 10 feet.

10 to 12 feet.

SOULANGEANA, 3 to 4 feet.

Iaple-ASH-LEA VED, Box E1der

$\begin{array}{lll}66 & 66 & 2 \text { to } 4 \text { feet... } \\ 66 & 66 & 4 \text { to } 6 \text { feet... } \\ 66 & 66 & 8 \text { to } 10 \text { feet, } \\ 66 & 66 & 10 \text { to } 12 \text { feet, } \\ 66 & 66 & 12 \text { to } 14 \text { feet, } \\ 66 & \text { 66 } & 14 \text { to } 16 \text { feet, } \\ 66 & \text { NORW A } & \text { very desirable, }\end{array}$

$21 / 2$ inch stem

3 to 4 inch stem

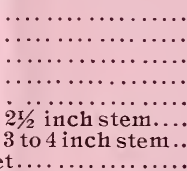

$\ldots \ldots \ldots \ldots \ldots \ldots \ldots \ldots \ldots \ldots \ldots$

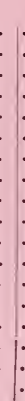

$10 \quad 100 \quad 1000$

$\cdots \cdots+\$ 1.00 \quad \$ 7.00$

$12.00 \ldots \ldots$.

15.00

$20.00 \ldots \ldots$

$25.00 \ldots \ldots$.

50.00

10.00

15.00

$6.00 \ldots \ldots$.

$10.00 \ldots \ldots$.

15.00

$1.50 \quad 8.00$

$\begin{array}{rr}2.00 & 12.00\end{array}$

$12.00 \ldots \ldots$

16.00

$22.00 \ldots \ldots$.

$30.00 \ldots \ldots$.

30.00

$25.00 \ldots \ldots .$.

25.00

3.50

..............

4.00
2.50

o.00….......

1.50

3500

3.50

\%.…......

1200

$18.00 \ldots \ldots$.

$10.00 \ldots \ldots$.

12.00

$15.00 \ldots .$.

20.00

25.00

$30.00 \ldots .$.

35.00

3.00

40.00

3.00

............

$30.00 \ldots \ldots$.

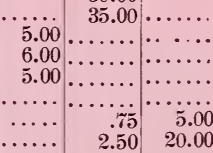

10.00

$15.00 \ldots \ldots$.

20.00 .

$30.00 \ldots \ldots$.

$40.001 . . . .$.

$12.00 \ldots \ldots$.

$20.00 \ldots \ldots$.

$25.00 \cdots \cdots$

$\begin{array}{rr}.75 & 5.00 \\ 2.50 & 20.00\end{array}$

$8.00 \quad 60.00$

$\begin{array}{r}10.00 \quad 90.00 \\ \hline\end{array}$

$15.00 \quad 125.00$

30.00 .

$40.00 \ldots \ldots$.

$12.00 \ldots \ldots$.

$18.00 \ldots . .$.

$25.00 \ldots \ldots$.

$35.00 \ldots . .$.

$12.00 \ldots \ldots$

$15.00 \ldots .$.

$2000 \ldots \ldots$

$\ddot{2} 0.60 \ldots . . .$.

$15.60 \ldots \ldots$

$18.00 \ldots .$.

$20.00 \ldots \ldots$

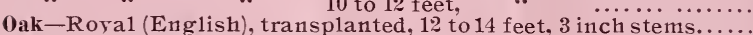
Peach-DOUBLE-FLOWERING, bri1liant crimson, 4 to 5 feet.

Pecan-Native, hardr, most delicious nut, 4 to 5 feet....

Poplar-BALM OF GILEAD, 6 to 8 feet.

8 to 10 feet.

10 to 12 feet.

14 to 16 feet.

6.00

2.00

3.00

$6.00 \cdots \cdots$

10.00

20.00 


\section{ORNAMENTAL TREES-Continued.}

\begin{tabular}{|c|c|c|c|c|}
\hline \multirow{2}{*}{\multicolumn{2}{|c|}{ 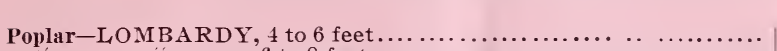 }} & 10 & 100 & 100 \\
\hline & & ... & & \\
\hline$\because$ & $\begin{array}{ll}\because . & 6 \text { to } 8 \text { feet. } \ldots \ldots \ldots \ldots \ldots \ldots \ldots \ldots \ldots \ldots \ldots \ldots \ldots \ldots\end{array}$ & & 7.00 & \\
\hline : & $\begin{array}{l}8 \text { to } 10 \text { feet } \ldots \ldots \ldots \ldots \ldots \ldots \ldots \ldots \ldots \ldots \ldots \\
10 \text { to } 12 \text { feet } \ldots \ldots \ldots \ldots \ldots \ldots \ldots \ldots\end{array}$ & & 8.00 & \\
\hline “ & 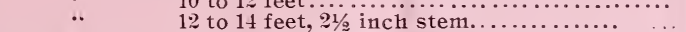 & & 20.00 & \\
\hline 6 & ASPEN LEAVED, 8 to 10 feet................... & 1.50 & & \\
\hline “ & 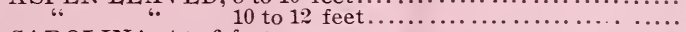 & 2.00 & & \\
\hline 66 & CAROLINA, 4 to 6 feet........................... & & 5.00 & \\
\hline "6 & " $\quad 6$ to 8 feet $\ldots \ldots \ldots \ldots \ldots \ldots \ldots \ldots \ldots \ldots \ldots$ & & 6.00 & \\
\hline 66 & 8 to 10 feet................................ & & 12.00 & \\
\hline alis & ria-Maiden 10 to 12 feet..... & & & \\
\hline cai & re-AMERICAN, (Buttonwood) 4 to 6 feet, transplanted... & & $\begin{array}{l}30.00 \\
12.00\end{array}$ & \\
\hline & "6 6 to 8 feet, " & & 15.00 & \\
\hline Tulip & ee-WHITE OR YELLOW POPLAR, 4 to 6 feet.. & & 12.00 & \\
\hline & $" 6 \quad$ " $\quad$ " $\quad 6$ to 8 feet............ & & 20.00 & \\
\hline 66 & 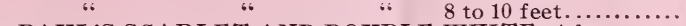 & 4.00 & & \\
\hline Thor & -PAUL'S SCARLET AND DOUBLE WHITE, 4 feet. . . . . & 3.00 & & \\
\hline Willo & $\begin{array}{l}\text { a Lutea-Yellow Wood. White F1o } \\
\text { GOLDEN, rapid, shows, } 4 \text { to } 6 \mathrm{fe}\end{array}$ & 3.00 & = 00 & \\
\hline 6 & GOL_LEN, rapid, showy, 4 to 6 fe & & 7.00 & \\
\hline "6 & " 8 to 10 feet.... & & 10.00 & \\
\hline "6 & 10 & & 12 & \\
\hline 66 & " $"$ " 12 to 14 feet............... & & 20.00 & \\
\hline 66 & FORBYANA-makes very $t$ & & 4.00 & \\
\hline 66 & LAU U REL-LEA VED, beautif $u 1,3$ & & & \\
\hline 66 & OSIER (Purpurea) Basket & & $\begin{array}{r}10.00 \\
2.00\end{array}$ & \\
\hline 66 & $\mathrm{YY}-\mathrm{LI}$ & & 12.00 & \\
\hline "6 & TRIANDRA-Immens & & 8.00 & \\
\hline$" 6$ & & & 10.00 & \\
\hline 6 & WHITE OR GRAY, 4 to 6 feet... & & 2.00 & \\
\hline 6 6" & "6 $\quad$ "6 $\quad 10$ to $12 \mathrm{f}$ & & 3.00 & \\
\hline 6 & BEVERIDGE OR STOCK, excellent for ear1y bee pasture; & & & \\
\hline & & & & \\
\hline 66 & 12 feet. & & & \\
\hline
\end{tabular}

\section{WEEPING TREES.}

\begin{tabular}{|c|c|c|c|}
\hline \multirow{2}{*}{\multicolumn{2}{|c|}{$\begin{array}{l}\text { Ash-EUROPEA N WEEPING, strong } \ldots \ldots \ldots \ldots \ldots \ldots \ldots \ldots \ldots \ldots \ldots \ldots \ldots \ldots \ldots \ldots \ldots \ldots \ldots \ldots \ldots \\
\text { Birch-CUT-LEA VED, WEEPING, elegant, } 5 \text { to } 6 \text { feet. } \ldots \ldots \ldots \ldots \ldots \ldots \ldots \ldots\end{array}$}} & $\begin{array}{l}10 \\
\$ 6.00\end{array}$ & \\
\hline & & $\therefore \ldots$ & \\
\hline \multicolumn{2}{|r|}{ Cherry-WEEPING, very ornamental . . . . . . . . . . . . . . . . . . . . . } & & \\
\hline \multirow{2}{*}{\multicolumn{2}{|c|}{ 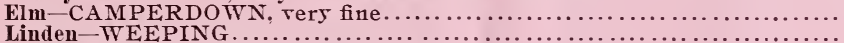 }} & 6.00 & \\
\hline & & 7.50 & \\
\hline \multicolumn{2}{|r|}{ 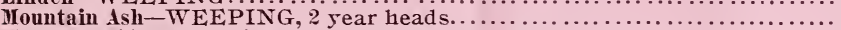 } & & \\
\hline \multirow{2}{*}{\multicolumn{2}{|c|}{ 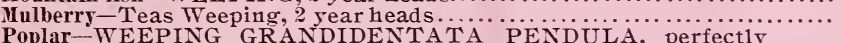 }} & 5.00 & \\
\hline & & & \\
\hline \multicolumn{2}{|r|}{ 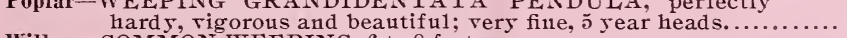 } & & \\
\hline & 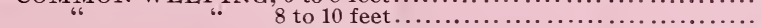 & & \\
\hline & $\ldots \ldots \ldots \ldots \ldots \ldots \ldots \ldots \ldots \ldots \ldots$ & & \\
\hline$\because 6$ & JAPAN, 6 to 8 feet....... & & \\
\hline 66 & KILMARNOCK WEEPIN & & \\
\hline 66 & WISCONSIN WEEPING, h & & \\
\hline 66 & 6 & & \\
\hline 6 & 66 & & \\
\hline 66 & & & \\
\hline & & & \\
\hline
\end{tabular}

\section{ORNAMENTAL SHRUBS.}

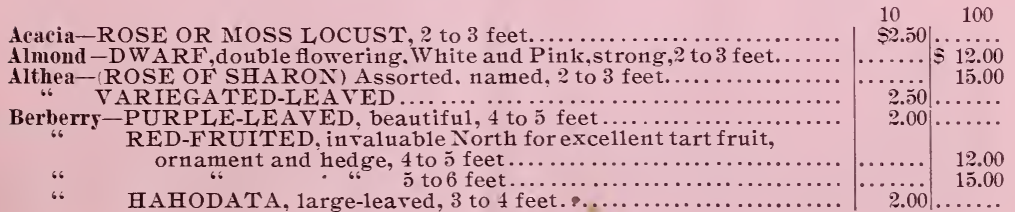




\section{ORNAMENTAL SHRUBS-Continued.}

Calycanthus-CAROLINE ALLSPICE, sweet-scented shrub, 2 to 3

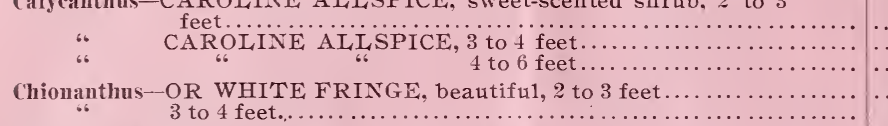

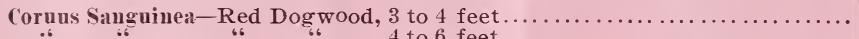

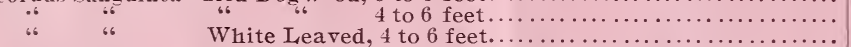

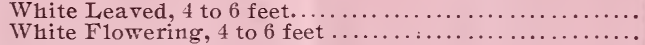

('urrant--Fragrant Missouri, 2 to 3 feet.

Daphme-MEZEREON, the earliest flowering shrub we hare. Two

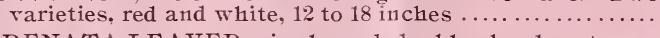

Dentzia-CRENATA-LEAVED, single and double, hardy, strong, FORTUNI, SCABRA, AND ROUGH-LEA VED, 3 to 3 feet

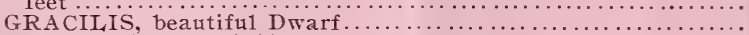

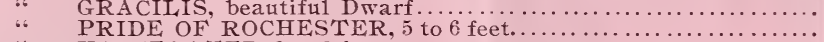

VARIEGATED, 2 to 3 feet.

Enonymous-STRAIBERRY TREE OR BURNING BUSH, two varieties, American and European, 4 to 6 feet.

Forsythia Viridis-GOLDEN BELL, deep green, very ear15, yellow

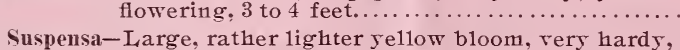

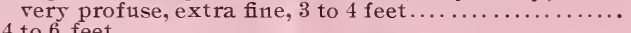

2.00 .. 4 to 6 feet.

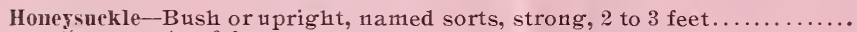
4 to 6 feet.
6 to $r$ feet.

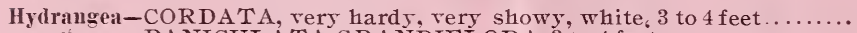

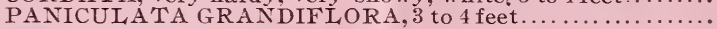

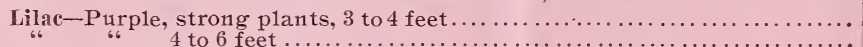

"6 4 to 6 feet

Persian, 2 to 3 feet.

ROTHOMAGENSIS, a hybrid variety, with reddish flowers, 4 to 6 feet.

Privet -18 to 24 inches.

CALIFORNIAN, 18 to 24 inches.

Purple Fringe or Smoke Tree-3 to 4 feet..

Plum-PRUNUS TRILOBA, double flowering, 3 to 4 feet.............. Quince-JAPAN SCARLET, in variety, 2 to 3 feet

Snowball- -2 to 3 feet ।

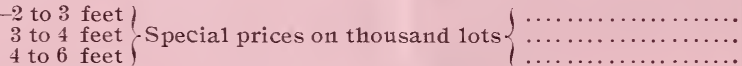

Snowberry-(SYMPHORICARPUS) RACEMOSUS, white andred, 2

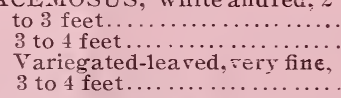

Spire:-A11 hardy. BILLARDI, COLOSA, ALBA, DOUGLASII REVESII, SALICIFOLIA,LINDLEYANA, SEMPERFLORENS, AUREA, ULMIFOLIA, OPULIFOLIA, FORTUNEI, PRUNIFOLIA, VAN HOUTEI, etc., 2 to 3 feet. .

"OPTLIFOLIA and VAN HOUTEI, 4 to 6 teet...

\begin{tabular}{l} 
\\
$\cdots$ \\
$\cdots$ \\
$\cdots$ \\
$\cdots$ \\
$\cdots$ \\
$\cdots$ \\
$\cdots$ \\
$\cdots$ \\
\hdashline \\
\hdashline \\
$\cdots$
\end{tabular}

Syringa (MOCK ORANGE), 'AUREA, CORONARIUS, DIANTHI-

FLORUS, GORDONII, GRANDIFLORA, MULTIFLOR ^, 2 to 3 feet.

Tamarix-AFRICAN, pink flowers, popular, 2 to 3 feet. 


\section{HARDY VINES AND CREEPERS.}

If sent by mail add 10 cents to price for each to pay postage.

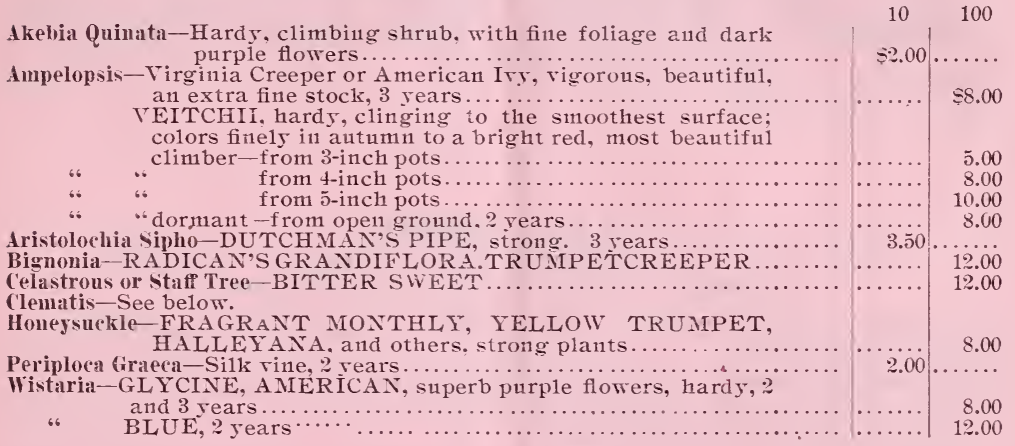

\section{CLEMATIS}

Al1 hardy. Home grown. On own roots.

Duchess of Edinburgh--Double white, of rigorous habit, free bloomer,

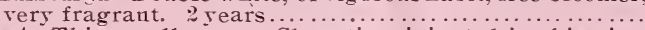

General frant-This excellent ner Clematis originated in this city. It is supposed to be a hybrid of Velutina Purpurea and Gem. Growth very strong and vigorous. Vers hardy. Large flowers of the Henryii type. Petals well rounded. Of the brightest relrety reddish purple, shaded with bright red. This is the first American Clematis, of extra fine merit, and undoubted15 new shades of color, in large flowering Clematis. It has been tried here for six years, and has proved to be unusually hard $y$ and free blooming. 2 years.

Henryii-New, and one of the best perpetual hrbrids, of robust habit. and rery free bloomer. The flowers are large, white. and

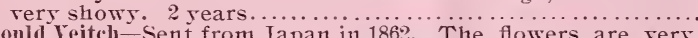

John Gould Yeitch-Sent from Japan in 1862. The flowers are very hand some, distinct, large, double, and of a light blue or 1arender color. It is like Fortunei, except in the color of the flowers. June and Ju1y. 2 years...

Jackmanii-Deep riolet purple, flowers produced in masses; one of

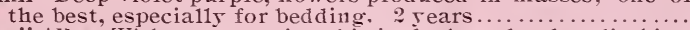
Jackmanii Alba-Without exception this is the best hardy climbing
plant that has been sent out for many years. It has a11 the characteristics of the Jaclsmanii, being free blooming and as vigorous. The flowers are nearly pure white, and make a fine contrast when planted near Jackmanii. It has been tested for years and has always won favor wherevershown. Strong

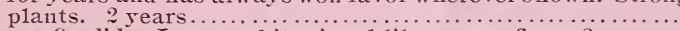

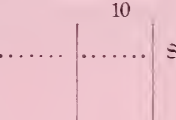

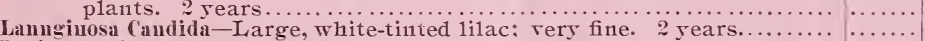

Lucie Lemoine-New, flowers white, double, large and well forned, composed of $\tau$ to 90 sepals: rery showy. 2 sears........................

Niss Bateman-One of the most charming of the Spring flowering $\mathrm{H}_{5}$ brids, having large white flowers with chocolate-red anthers, and somewhat fragrant. Mas and June. ? years.......................

Madame Edontad Andre-A new French variety, entirely distinct and most nore1. The nearest approach to a bright red ret produced. This Clematis was exhibited at the World's Fair, Chicago, in the French Department, and attracted great attention, owing to the brilliancy of its flowers. The plant is a strong, rigorous grower. being a hybrid of the popular Jackmanii rariet5, which it resembles in freedom of bisom. strong, rigorous growth, shape and size of flowers. 2 Jears...

Magnifica-A magnificent free blooming rariets. Color, a deep lasender blue; flowers large and finely formed. Strong grower.

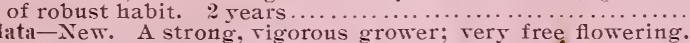

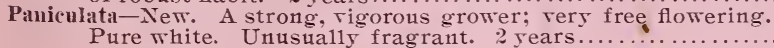




\section{CLEMATIS-Continued.}

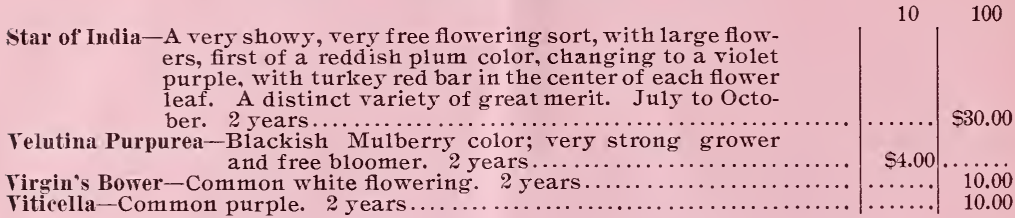

\section{PLATE BOOKS.}

\section{COLORED PLATES OF FRUITS AND FLOWERS.}

Our stock is composed of hand painted plates-all new, handsome, and showy, and the best in the market.

Size, $5 \frac{1}{2} \times 9$, with printed description at bottom of each plate.

Price, 8 cents per plate, binding extra.

Plate books made promptly to order.

When bound in ordinary book form, with name and add ress printed on cover, a charge of $\$ 1.00$ is made for binding.

When bound in folio form, and arranged so as to show six to twe1ve Plates at once, making a beautiful and attractive combination of colors, a charge of $\$ 1.50$ is made for binding.

A11 books bound so that more plates can be added.

Bound books of plates genera11y on hand. Prices on application.

List of plates free on application.

Can furnish Lithog raph plates of most varieties offered, at $\mathbf{5 c}$ per plate.

\section{NURSERYMEN'S REQUISITES.}

Articles not found in the following list will be priced on application.

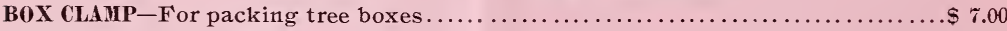

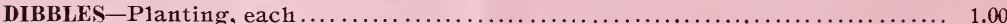

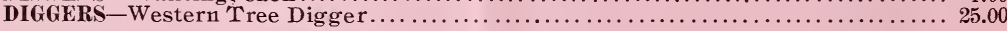

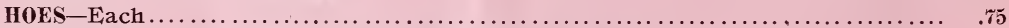

HOOP IRON-For strapping boxes-ready for use-per 1 b. $\ldots \ldots \ldots \ldots \ldots \ldots \ldots \ldots \ldots .12$

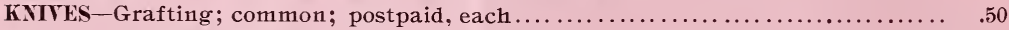

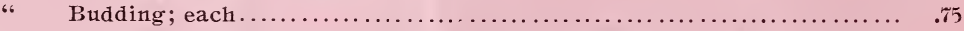

LABEIS-Judson's-Tree; pierced, 4 inch, wired, 15c. per 100; 1,000, \$1.25; unwired

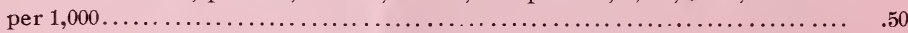

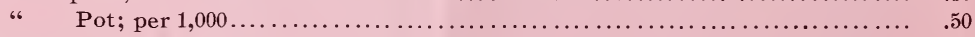

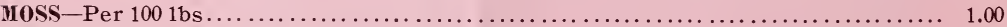

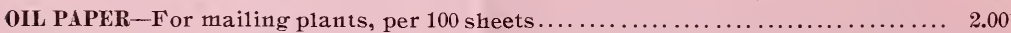

ORDER BOOKS-25 orders and 25 perforated duplicate sheets, postpaid, $25 \mathrm{c}$ each;

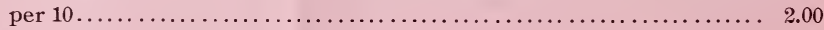

PLATES-Colored. See P1ate Department (above).

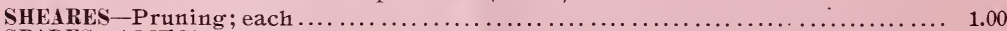

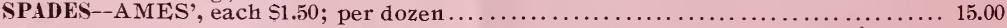

TAGS-Shipping; printed to order; size $5 \times 21 / 4 ;$ per $1,000 \ldots \ldots \ldots \ldots \ldots \ldots \ldots \ldots \ldots \ldots . . .2 .00$

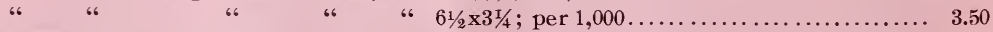

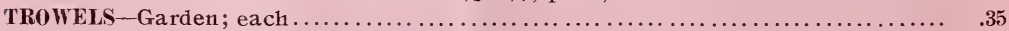

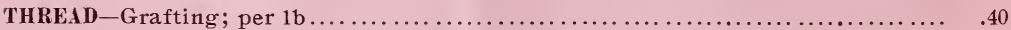

"6 "6axed, ready for use, sufficient to wrap $20,000 \mathrm{~g}$ rafts $\ldots \ldots \ldots \ldots \ldots \ldots \ldots$

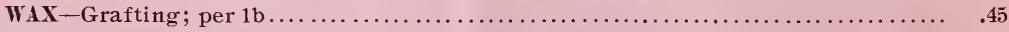

WIRE-Brass, for labels; per 1 b., cut ready for use $\ldots \ldots \ldots \ldots \ldots \ldots \ldots \ldots \ldots \ldots \ldots \ldots .60$

WILLOWS-For tying and making baskets, 3 to 5 feet long. Per $100 \mathrm{lbs}$, $\$ 1.50$; per

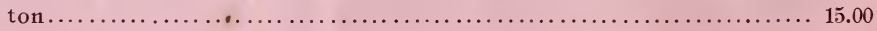




\section{GREENHOUSE AND BEDDING PLANTS.}

\section{ROSES, HARDY AND TENDER BULBS, ETC.}

Thirty Thousand Square Feet Inder Glass for plants and propagating purposes, gire us unusual facilities; so we can truly say our plants are in most splendid health and rigor, of the best size and shape for packing, and put up in the most approred style for safe transit. They are usually sent by express, for which there are exce1lent facilities at this point.

Where practicable, small plants will be sent by mail, cost of postage added; we sha11, howerer, send a11 packages by express at purchaser's expense, unless specia11y ordered otherwise. The adrantages are obrious. Larger and better plants can be shipped, and they usually arrive in better order, with fibrous roots intact, ready at once to sustain life. By mai1, more or less soi1 is remored, unaroidab1y breaking roots, compelling the plant to make new roots, which it does quick $1 y$ if conditions are farorable, or lingers for days or even weeks before it starts, much to the annoyance of the purchaser, who, no doubt, frequent1y exclaims, "I wish I had taken their adrice and had them sent by express." With our many years of experience, we claim to be as successful in sending by mail as any. It is, howerer, the unanimous rerdict of all florists, that expressing has many adrantages orer plants sent by mail. P1ants or bulbs of a bu1kr nature wi1l, in a11 cases, be sent by express or freight. Extra plants will be added to corer expressage.

Purchaser's selections glad1y allowed, and the choice new rarieties usually included in sets of tens, as far as practicable, without extra charge.

We cannot afford to fill orders for less than $\$ 1.00$ at the prices named herein.

\section{ROSES.}

We make the growing of roses a specialty. Our list of rarieties has been careful1y selected so as to include only the rery best. We are constantly buying the newer varieties and after giring them a fair trial, discard such as are not found worthy of cultiration and of distinct character.

OUR ROSES are a11 grown on their own roots, either from cuttings or layers. We do not consider budded roses good for permanent out-door planting, the difference being the Mannetti or stock on which roses a re budded makes such a strong growth and sends up so many suckers that it usually kills out the rariety to which it is budded the first year, and takes its place, and nothing is left but the common or stock rose, unless of course the grower is rery familiar with the cultiration of roses, and knows the difference between the stock and the bud and when to prune and pinch back.

We recommend pot-grown Month1s and Hrbrid Perpetua1 Roses as best for spring planting. Being in a growing condition when receired, the $y$ are a1most certain to lire. and from the fact that none of the sma11, fibrous roots are disturbed in transplanting, each plant being balled separate when taken from the pots, and all the roots left intact. Starting to grow at once the $y$ bloom earlier than dormant plants.

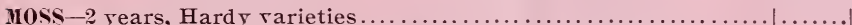

Blanche Moreau, John Cranston,

Capt. John Ingram.

Countess de Murinais,

Crested.

Henry irartin.

Luxembourg.

Princess Adelaide.

Perp. White MIoss,
Raphae1,

Red Moss,

Reine Blanche,

Salet,

CLIMBING-2 and 3 years, Anna Maria, Baltimore Be11, Eva Corinne,

Gem of the Prairie, Prairie Queen. Pride of Wrashington,

Russel1's Cottage, and Seren Sisters. 


\section{ROSES-From Pots.}

HYBRID PERPETUAI-F rom 4 inch pots............................... 10.100

Achille Gonod, Anna de Diesbach, Aif red Colomb, Anton Mouton. Augusta Mie,

Baron de Maynard,

Baron de Bonstettin,

Belle Normandy,

Black Prince,

Caroline de Sansal,

Capt. Christy,

Charles Leferre,

Cheshunt Hybrid,

Coquette de Alpes,

Coquette des Blanches,

Countess of Roseberry,

Dinsmore,

Dr. Hovey,

Duke of Connaught,

Duchess de Carlus.

Duchess of Mornay,

Ear1 of Pembroke,
Emperor of Morocco,

Empress of India.

Eugene Forey,

Eugene Joret.

Fanny Petzold,

Gen. Washington,

Gen. Jacqueminot,

Glory de Margottin,

Gustave Pigareau,

Jean Lelivers,

Jean Liabaud,

John Hopper,

Jules Margottin,

Josephine Marot,

Lady Helen Stewart,

LaReine,

La France,

Louis Odier,

Madam Masson,

Madam Alfred Carriere,

Mad. Charles Wood,

Madam La Charme,
Miad. Francois Petit,

Mad. Isaac Perreau,

Mary Washington,

Marie Bauman,

Marquis Bocella,

Marshal1 P. Wilder,

Magna Charta,

Mrs. Forey,

Mrs. John Laing,

Mons. E. Y. Teas,

Pronia,

Paul Ney ron,

Prince Camille de Rohan,

Reine Marie Hen rietta,

Sourenirde William Wood,

Senateur Vaisse,

U1rich Brunner,

Victor Verdier,

Viscountess Folkstone,

Vick's Caprice,

William Chesbrough,

Xavier Olibo. yохтиц -Including Teas, (hina, Noisette and Bourhou, 2 years,

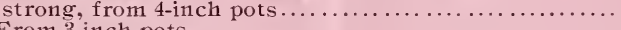

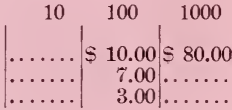

Agrippina

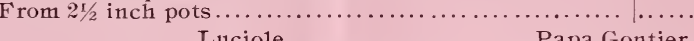

Beaute Inconstant,

Bon Silene,

Luciole,

Bougere,

Madam A. Chatenay,

Madam Claudia Perreau,

Madam Emilie Charin,

Pear1 Rivers,

Perle des Jardin,

Princess Radiziwe11,

Bride, Madam Falcot,

Countess Riza du Parc, Madam Piere Guillot,

Devoniensis,

Madam Phillipa

Maria Guillot,

Marecha1 Neil,

Mary Washington,

Dr. Gril1,

Edward Gontier,

Etoille de Lyon,

Miss Ethel Brownlow,

Migonette,

Mrs. DeGraw,

Golden Fairy,

Hermosa,

Henry M. Stanley,

Isabella Sprunt,

Lady Castlereagh,

Mrs. Pierpont Morgan,

Mrs. W. C. Whitney,

Niphetos,

Princess Sogan

Queen's Scarlet,

Rainbow,

Regulus,

Sappho,

Safrano,

Sourenir de Laurent Guillot

Souvenir de Malmaison,

Sunset,

The Queen,

Washington,

W. A. Richardson,

White Banksia,

Parquette,

HYBRID TEA-From 4 -inch pots............................... $\$ 10.00$

Souvenir de Wooten,

Madam Schwallers,

La France,

Duchess of Albany,

Visconntess Folkstone,

Antoine Verdier,

Meteor,

Augustine Guinosseau,

Madam C. Testout,

Augustine Halem,

Belle Siebrecht,

\section{ROSES-Dormant.}

HIBRID PERPETLAL--on own roots-Leading, hardy varieties; dormant; from the open ground, 2 jears, strong...

Eugene Forey,
Empress of India,
Fannie Petzold,
Gen. Jacqueminot,
Gen. Washington,
Lady Helen Stewart,
LaReine,
Louis Odier,
Madam Plantier,
Madam Trotter,
Madan A1fred Ca rriere,
Mary Washington,
Mons. E. Y. Teas,

Mad. Isaac Perreau,

Achille Gonod,

Anton Mouton,

Augusta Mie,

Belle Normandy,

Black Prince,

Beauty of Wa1tham,

Caroline de Sansa1,

Coquette des A1pes,

Duchess de Caylus,

Dinsmore,

Duke of Connaught,

Enfant Mt. Carme1,

Eugene Joret,

Mons. E. Y. Teas,

Madam La Charme,

Marquis Bocella,

Marie Bauman.

Magna Charta,

Paul Ney roi1,

Pæonia,

Prince Alberl,

Reine Marie Henrietta,

Senateur Vaisse,

Vick's Caprice.

William Chesbrough,

SWEET BRLAR-O1d English variety; very hardy; makes a beautiful hedge. Foliage very fragrant. 2 year plants, 2

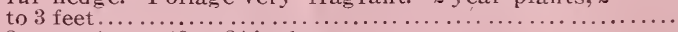




\section{NEW ROSES AND ROSES OF SPECIAL MERIT.}

American Beauty-Hybrid Perpetual. An excellent hardy Rose fo permanent planting. Fu11y equal to General Jacqueminot in hardiness. Larger in size of bloom. Very double and of a fine crimson pink. Also considered the finest red rose for forcing, and alwars bringing the best price in the largest flower mark-

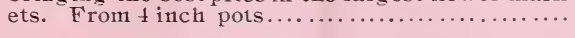

From 6 inch pots.

Augustine Halem--Hybrid Tea. Extra large and handsome. Color, dark crimson. A beautiful free blooming rose, and very fragrant. From 4 -inch pots..............

Augustine Guinossean-Or White La France. Color, a lorely flesh or

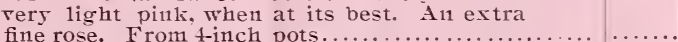

Baron de Maynard-Hybrid Perpetua1.) Flowers very large and perfect in form. Pure white. strong, rigorous grower; profuse bloomer throughout the season. From

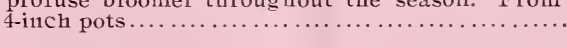

Beauty of Waltham-(Hybrid Perpetua1.) Very strong, rigorous, free blooming: large flower; rosy carmine: Dor-

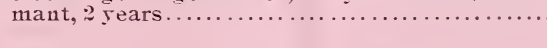

Belle de Normandy--(Hy brid Perpetual.) Splendid large full flowers. clear rose, shaded rosy carmine and lilac. Dor-

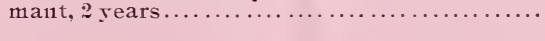

Belle Siebrecht-A truly superb Rose. Color, imperial pink. The flowers, which are sweetly perfumed, are large, beautifully formed, and of that long, tapering shape, with high center, and when half blown. the petals reflex in a graceful manner. It is a free and rigorous bloomer. with large and gloss $y$ foliage of leathery texture. entirely free from mildew. One of its best qualities is that it holds its color after cutting

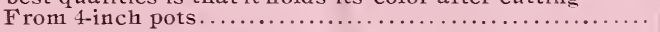

Bon Silene-(Tea.) Deep ross pink, shaded crimson. Semi-double.

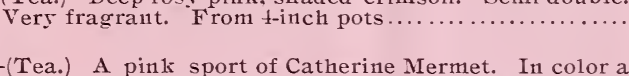

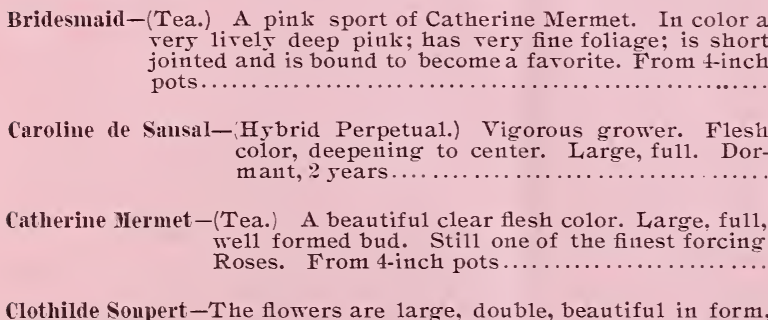

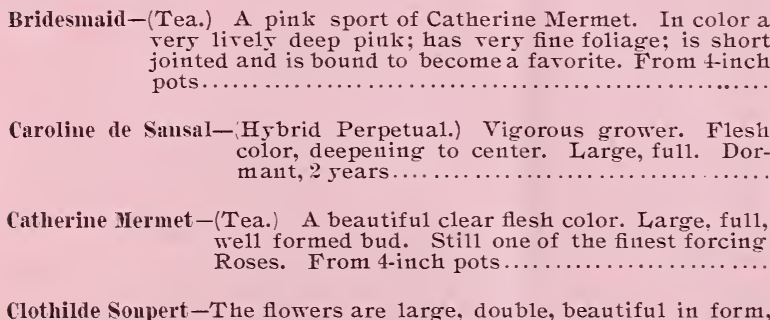

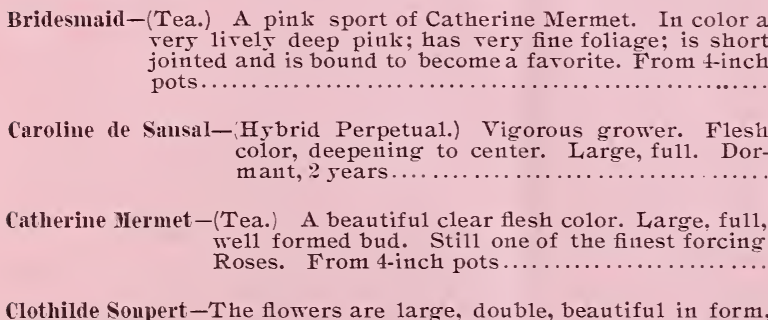

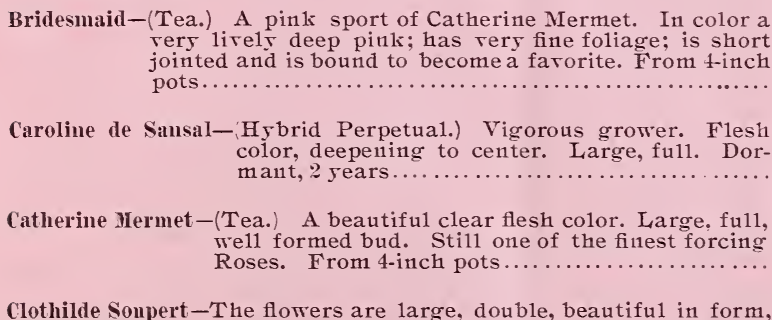

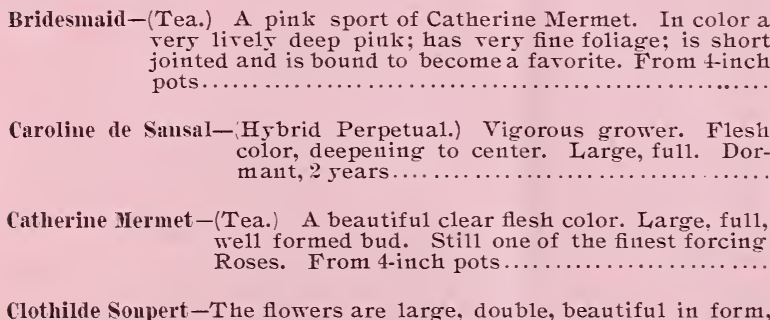

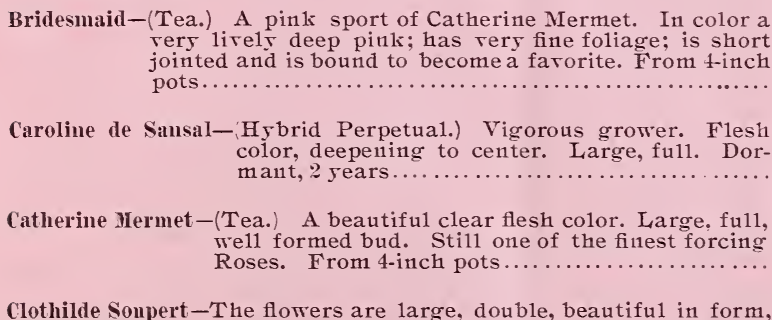

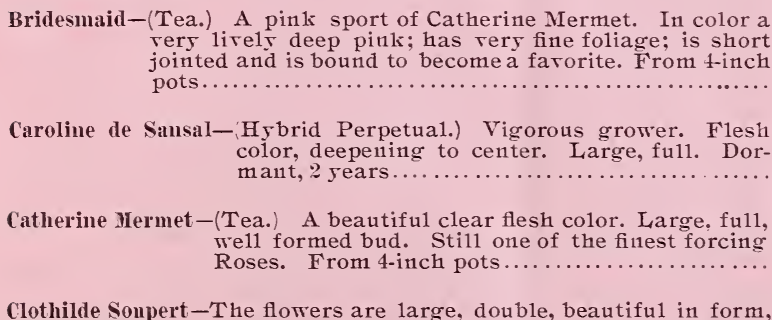

and borne in sprays. The color blends from a soft
she11 pink to a pure white. Roses with both of
these colors are produced on the'same plant at the
same time. We consider it to be the best white
bedding rose. It is rers hards and stands out
over winter here. From $21 / 2$-inch pots...........................

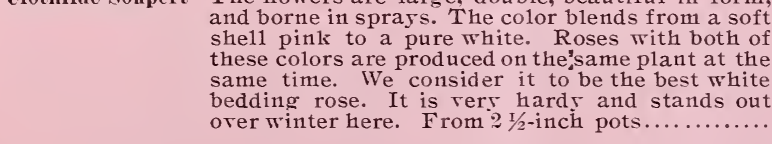

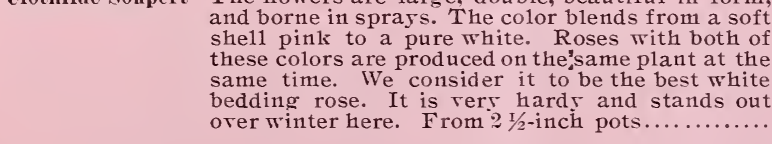

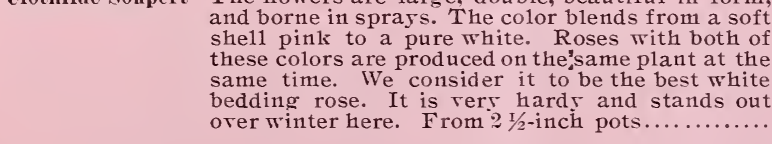

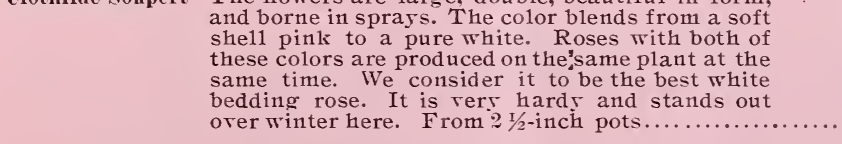

From 4-inch pots

$$
\text { From 4-inch pots. }
$$

Coquette des Blanches-A finely formed, pure white rose; occasionally shows light flesh when first opening; beautiful shell shaped petals, eren1y arranged. Flowers of good size, perfect, and of fine form and finish. One of the finest, freest, and most beautiful of the white hybrids. Very suitable for cemeters planting Dormant 2 years and from 4 -inch pots. 


\section{New Roses and Roses of Special Merit-Continued.}

Corime-(Hybrid Tea.) A new English rose of great promise; it has taken the gold medal in London and sereral certificates of merit. The color is a beautiful flesh, shaded with rose and suffused with tawn copper. The flowers are of large size, excellent shape and very freely produced. We recommend it as a dwarf, rigorous rose, that will produce an abundant crop of large, double, pink roses during the entire summer.

From 4 inch pots ............................................ Dinsmore - This fine rariety possesses all the desirable qualities of a
bedding rose-good color, fine form, a profuse bloomer, and stands the rigor of our Northern winters without protection. The flowers are large, perfectly double, and of a dazzling scarlet crimson color, and have that rich, spicy fragrance peculiar to the best hybrid Roses.

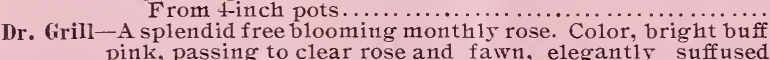
pink, passing to clear rose and fawn, elegantly suffused

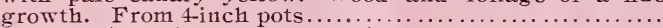

Duchess de Caylus-(Hyrid Perpetua1.) Extra large flowers, very double, fu11, perfect form, rery fragrant; color, rich cherry red, sometimes brilliant crimson, delicately tinged with

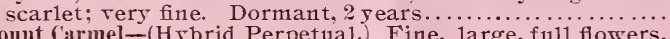

Enfant Mount C'armel-(Hybrid Perpetual.) Fine, large, fuil flowers, bright deep rose, elegantly shaded; rery sweet, hardy and good. Dormant, 2 years .............................................. Tea Roses. It blooms freely and erery flower is a gem. It equals Marechal Nei1, on strong bushes. Color, a deep

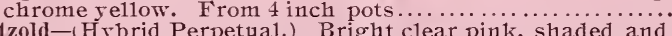
vol (Hith violet purple, harge, hand pome, Dormant,

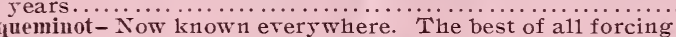

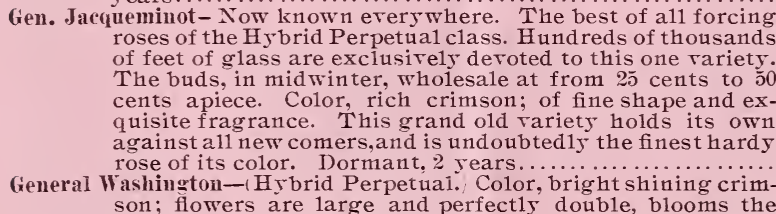

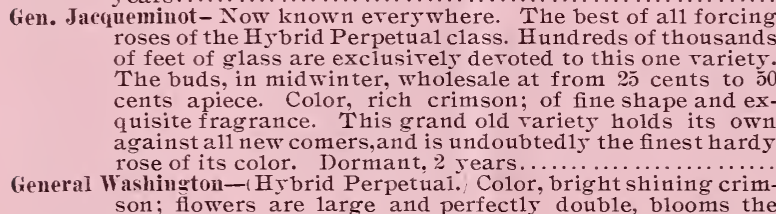

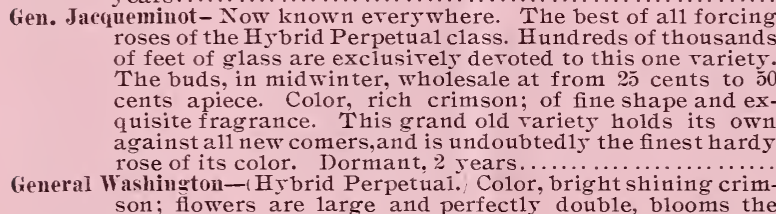

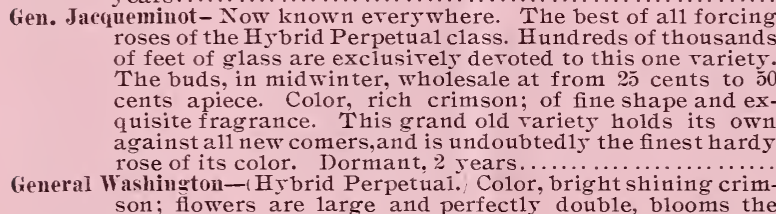

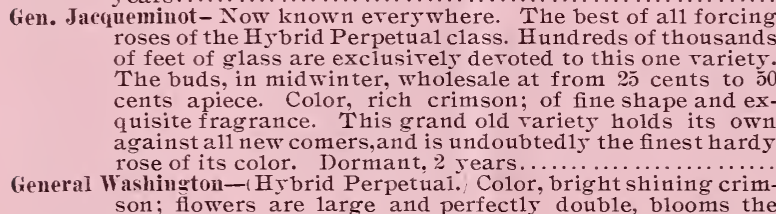

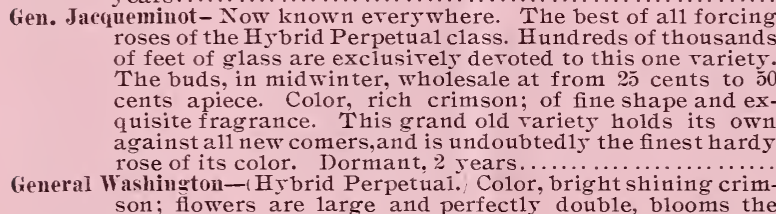

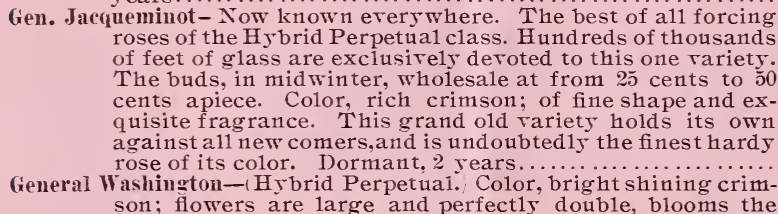

10

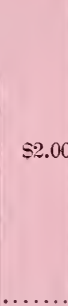

10.00

10.00

10.00

10.00 son; flowers are large and perfectly double, blooms the

first season and almost constant1y. Dormant, 2 years...........
Hermosa - (Bourbon. A1ways in bloom and always beautiful. The flower is cupped, finely formed, and fuli; color, the most pleasing shade of p!nk; very fragrant. A favorite witis erery one. Dormant, 2 years.........................................

Kaiserin Augusta Victoria-New Forcing Rose-This beautiful rose has not on1y a royal name. but is a royal rose as well. We hare white roses that have elegant buds, but when full blown are not all that is desired. Then again, we have white roses that are elegant when full blown, but have poor buds. 'This rose combines both these good qualities. It is a continuous bloomer, producing successive crops of buds, and formed with large petals of best substance; shows no center when fully open. Color a pure snowy

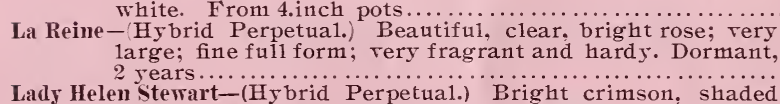

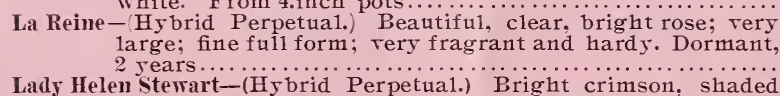

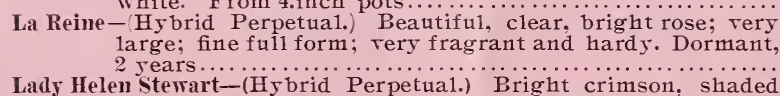
scarlet; a good grower and abundant bloomer. Dormant,

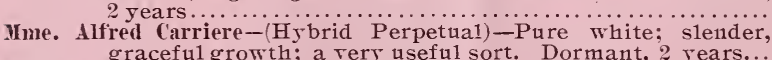

Iadam C. Testout-A grand rose of the La France type, but larger and better color. It is a clear pink, rery fragrant, and a splendid forcing variety.

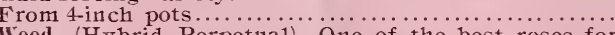

Madam Chas. Wood-(Hybrid Perpetua1)-One of the best roses for
planting erer introduced; the flower is extra large,full and planting erer introduced; the flower is extra large,full and
double; color, deep rosy-crimson, sometimes brilliant and scarlet with maroon shading. A constant and profuse bloomer.

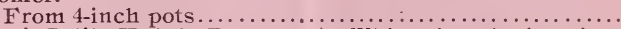

Madame Francois Petit-(Hybrid Perpetual)--White tinged with pink, Very free and hardy.

From 4-inch pots.. 


\section{New Roses and Roses of Special Merit-Continued.}

Madam Masson-- Hybrid Perpetua1)-B1oomsnearly a11 the time, and bears plenty of large, full flowers; color clear bright rose; very sweet; handsome.

From 4-inch pots.

Iaman Cochet--(New Tea Rose--One of the best new roses for 1895. The growth is rigorous, with rich, healthy foliage. The extra large flowers are produced on 10 g stems, are very double, and the buds and half-expanded flowers are simp1y exquisite in their graceful form, delicate color, and rich fragrance. The color is deep rose pink, the inner side of petals silvery gray. This variety was illustrated and described in the "Journal des Roses" two years ago, and one thousand dollars was refused for the stock by the originator, Mons. Cochet.

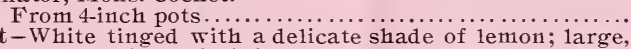

Iarie Guillot - White tinged with a delicate shade of lemon; 1arge, fu11 and beautifully imbricated in form; one of the finest
white Teas; the perfection of form in Tea Rose; highly fragrant. The best White Tea Rose for bedding.

From 4-inch tops........................

Mary Washington--A hardy, perpetual biooming climber, producing double snow-white blossoms in clusters and great profu-

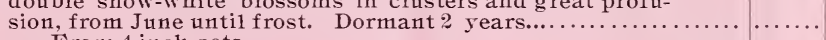

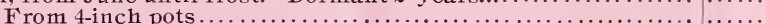

Iarechal Teil--The king of yellow climbers. Hardy south.

Ieteor-Hybrid Tea Rose. Color is rich relrety crimson, exceedingly bright and striking. Both buds and flowers are large and of excellent form, full, double, borne on long stems.

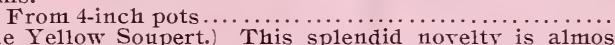

Mosella-(The Yellow Soupert.) This splendid norelty is almost
identical with that of the original Soupert. It blooms in identical with that of the original Soupert. It blooms in
profuse clusters of three to five flowers, which are very double, ball shaped and open like a Camelia flower. The petals are tinted white, on beautiful light yellow ground, extending to the middle of the petals. The plant is dwarf, bushy and free blooming. It is sure to be a popular companion to the original Clothide Soupert.

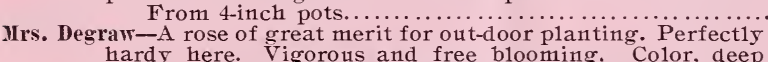
pink. Very fragrant. We beliere this to be the best pink

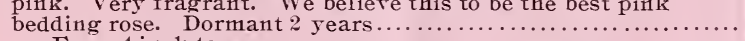

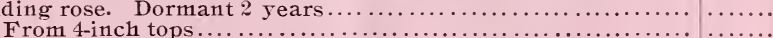

Niphetos--Very large and double. Color, pure white. Highiy ralued for its lovely buds, which are large and pointed. This rariety is extensively grown where white buds are in demand.

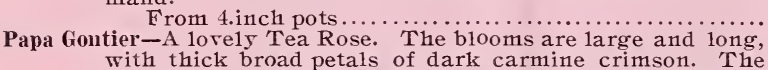
with thick broad petals of dark carmine crimson. The
inner petals are of a bright rosy carmine. The most popular forcing rose of its color.

From 4-inch pots.

Paul Yeyron-(Hybrid Perpetual-A beautiful shade of deep rose, occesionally lightening to satiny pink in the center. One of the rery largest, if not the largest, rose in existence. The branches are long and the foliage is superb, in keeping with the flowers; few thorns. Full, double, fragrant flowers. No collection complete without it. Dormant 2 years, and from 4 -inch pots.

Jardin-(Tea --Without doubt the finest yellow rose in cuitivation. Canary or golden yellow flowers. Large and beautiful form.

From 4-inch pots.

Rainbow-A grand rose. A sport from Papa Gontier, but a better bloomer. Color, pale she11 pink, striped with Gontier crimson. From 4 -inch pots...................................... The

Souv. de Prest. Carnot-(Hybrid Tea.) The finest rose presented to
the public in many years. In beauty of form it is simply unsurpassed, while to our taste it is the loveliest combinanation of pink and white tints that we have ever seen, and the great majority of people who hare seen it agree with us, for the admiration elicited by it is involuntary. In addition it is a strong grower, producing stiff, long canes; a free grower, with handsome foliage; it is easy to manage and easy to propagate.

From 4-inch pots 


\section{New Roses and Roses of Special Merit-Continued.}

Souv. de Malmaison-This is certain1y one of the choicest Roses in our collection, and for general cultiration unsurpassed. The color is a beautifu1 rich creamy flesh, distinctly and elegant1y shaded clear peachy red, with a rose center; flowers are rery large, perfectly double and deliciously fragrant. Particularly raluable for outside cultivation, being quite hardy. A strictly first-class rose in every respect. sure to give absolute satisfaction.

From 4-inch pots.

Sunset-Color is a shade of rich golden amber, tinged and shaded with a dark ruddy copper. Very beautiful.

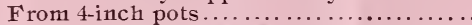

The Bride-A lore1y pure white, very fragrant rose. Splendid to force. The buds hare more substance than Niphetos. Are rery ful1 and double. The finest and most profitable of a11 the white roses for forcing.

From 4 -inch pots.

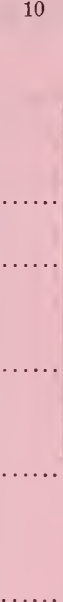
ard red, and very fragrant. The flowers are borne on long flower stalks, almost deroid of thorns.

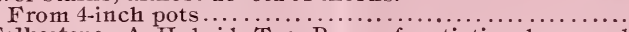

Viscountess Folkestone-A Hybrid Tea Rose of artistic shape and color. It forces readily, is of strong growth and bears lovely white flowers tinged sa1mon pink, slightly cupped and delightfully fragrant. The buds are of large size, pointed.

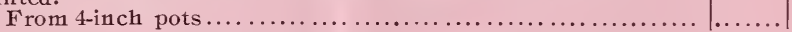

\section{New Hardy Climbing Roses.}

Crimson Rambler-A grand new Rose from Japan. The plant is of very vigorous growth, making shoots of from six to ten feet during the season, rendering it a charming pillar Rose. It is a1so magnificent in bush form, The flowers are of a glowing crimson, and are produced in great pyramidal panicles or trusses, each carrying from thirty to forty blooms, the individual flowers measuring about one to one and one-half inches in diameter, and remain perfect on the plant for upwards of two weeks. The foliage is bright green and glossy and perfectly healthy. We find this Rose perfect1y hardy here.

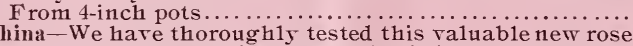

Empress of China-We have thoroughly tested this raluable new rose
for sereral years. Its distinct quality is its habit of true perpetual blooming, which is possessed by no other climbing rose in anywhere near the same degree. It is perfectly hardy, having withstood our severe winters here. The vigor of growth is unsurpassed. The flowers are sma11, but very delicate, waxy and fragrant, and are borne profusely. The color is a soft dark red in hud, and changes as the flower opens or grows older, to a lighter shade of

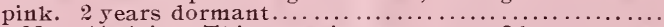

Yellow Rambler-(Aglaia)--This rose is, we are confident, an even
more valuable introduction than the Crimson Rambler, for it is the hardiest yellow climbing rose yet introduced, and quality of hardiness has been an extremely difficult one to combine with yellow color. We believe that, with very slight attention, it can be grown everywhere that other roses succeed. Yellow Rambler is a blood relation to the Crimson Rambler, which it much resembles in growth and foliage. It also blooms after the same manner as Crimson Rambler, in large trusses, often as many as 120 to 150 flowers in a bunch. The flowers are very sweetly fragrant, and last three to four weeks without fading.

From 4-inch pots.

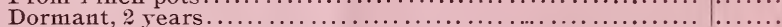

\section{HARDY HERBACEOUS FLOWERING PLANTS.}

The following assortment embraces the most desirable kinds and varieties. They are al1 showy, beautiful plants, of easy cultiration and of various seasons of flowering, from May to November.

Anemone Whirlwind-A new, semi-double form of Anemone JaponicaAlba, which is supposed to be a cross between this beautiful variety and a Japonica Rosea. In general style and habit it is identical with the white Anemone. It is of the same strong habit of growth, and is even more free-flowering than the original type. The flowers, which are $21 / 4$ to 3 inches across, hare sereral rows of pure white sepals, and the advantage of lasting much longer than the single rarieties. 


\section{Hardy Herbaceous Flowering Plants-Continued.}

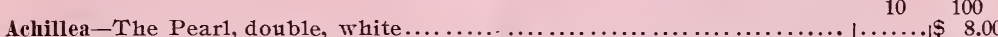

Authirrhinunt-Snowflake, white Snap Dragon. Fine for summer

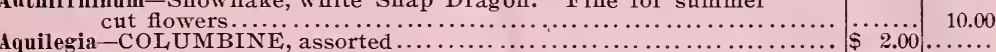

Astilbe-JAPONICA, SPIREA, June to August. Beautifu1 large spikes of pure white flowers and elegant foliage................. COMPACTA MULTIFLORA. This new variety, from 8 to 10 inches in height, produces larger and finer blossoms

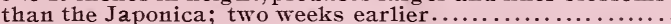

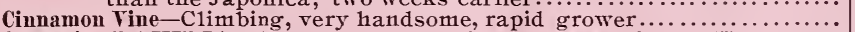
Clematis-DAVIDIANA-B1ue, blooms in Clusters; Juis. Very

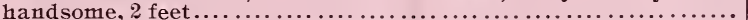

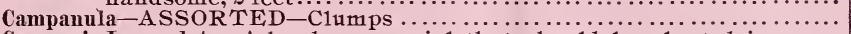

Coreopsis Lanceolata-A hardy perennial that should be planted in every garden. The flowers are clear bright yellow, very attractive. A profuse bloomer and perfectly hardy. Thrives in almost any situation. Invaluable for summer

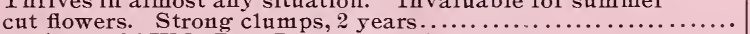

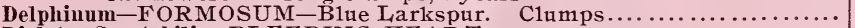
Dielytra Spertabilis-BLEEDING HEART..... E

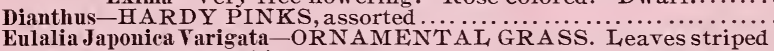

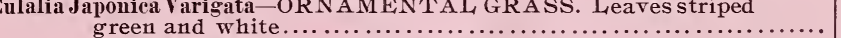

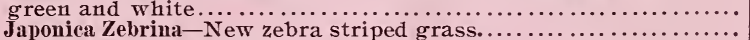

66 Japonica Zebrina-New zebra striped grass........................

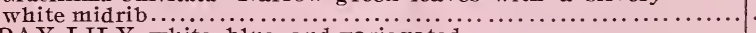

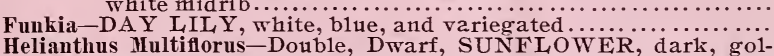
den yellow color, grows from 3 to 5 feet in height. Never fails to flower the first season of planting. One of the

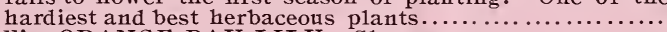

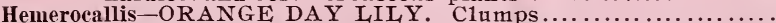

Hollyhock-Double, white, yellow, pink, red, sulphur, and maroon, from open ground.

Hibiscus-CRIMSON EYE. The stems and wood are deep red, and foliage is beautifully reined. Flowers immense. Color a clear, snow white, with a brilliant crimson eye...............

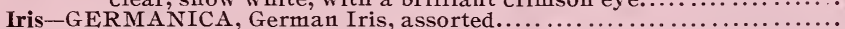

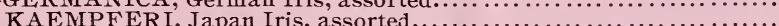

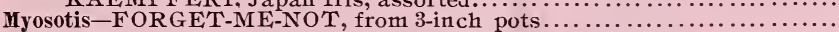

Pronies-Extra choice selection of best European and Japanese va-

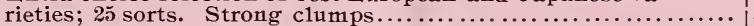

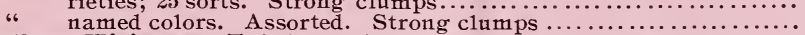

Pyrethrum Uliginosum-This is considered by many the finest autumn flowering plant we have, growing 4 feet high and covered with a profusion of large white flowers. Resembles the Paris Daisy in form of flowers. Very useful for fall cutting; August to frost..

Phlox-HARDY PERENNIAL. The improvement made in this beautiful class of plants the past few jears is perhaps more marked than in any other section of the Hardy Herbaceous family. Instead of the small flowers produced by the older varieties, which were almost limited in color to lilac and white, we now have gorgeous flowers combining all the various tints of rose, carmine, red, purple, white, and salmon, with their distinct eyes. They require no care but dividing and resetting every second year. Their vigorous growth and freedom of bloom make them very usefu1 plants. Perfectly hardy everywhere. We have about thirty sorts.

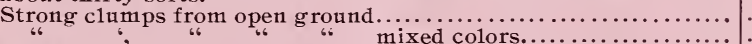

Rudbeckia Double, "GOLDEN GLOW." A glorious new plant and one that will find a place in every garden here and abroad: of fine habit, vigorous growth, with ear15, continuous and immense blooming qualities; it will be found excellent also for cut flower purposes, inasmuch as the stems are long and often carry a dozen flowers furnished with most beautiful foliage. A large vase filled with these flowers is a

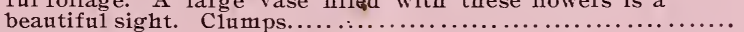

Violets-Hardy, Russian, double, large blue....................................

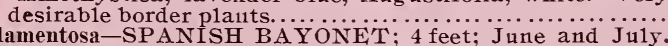

Yucca Filamentosa-SPANISH BAYONET; 4 feet; June and Ju1y.
Foliage evergreen and somewhat resembling the Century Foliage evergreen and somewhat resembling the Century
plant in habit of growth. The flower spikes are manybranched and the flowers are borne in huge panicles above the sword-shaped foliage. Large, white, waxy blooms.

8.00 


\section{TENDER BULBS AND TUBERS.}

FORMOSISSIMA, velvety crimson $\ldots \ldots \ldots \ldots \ldots \ldots \ldots \ldots \ldots \ldots$

" JOHNSONI, bright red.

Agapanthus Umbellatum-AFRICAN LIL Y, blue, from 6-inch pots . .......

Begonia Tuberous--Rooted--single mixed colors $\ldots \ldots \ldots \ldots \ldots \ldots \ldots \ldots \ldots \ldots$

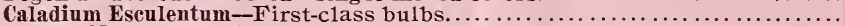

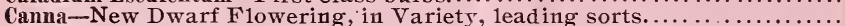

Cooperia Drummondii--EVENING STAR. Lovely fragrant flowers

of the purest waxy white.........

Dahlias-Assorted varieties, dry roots.

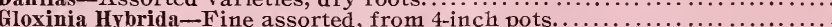

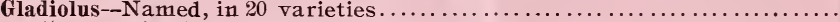

Mixed, a11 colors..

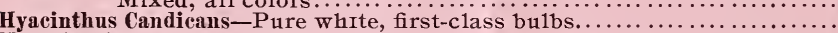

Maderia Vine-Strong bulbs.

Tuberoses - PEART and DOUBLE, flrst.

Tephryanthus-CA NDIDA, white...

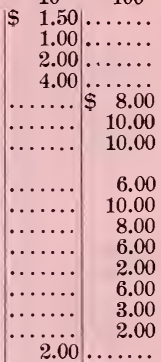

\section{HARDY BULBS.}

For Fall Planting. Mostly ready for shipment after September 15.

Our Bulbs are all First Quality.

yacinths-Finest named sorts, double and single $\ldots \ldots \ldots \ldots \ldots \ldots \ldots \ldots \ldots \ldots \ldots \ldots$. 8.00

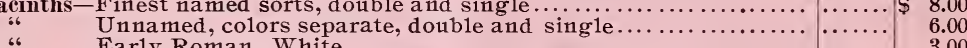

"6 Early Roman, White...................................... $\quad 3.00$

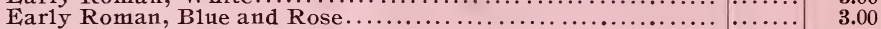

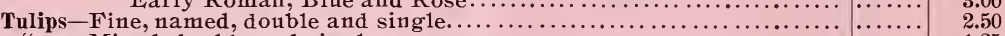

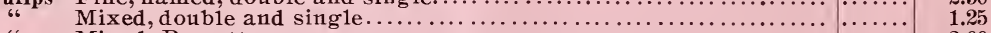

Mixed, Parrott.................................................. $\quad 2.00$

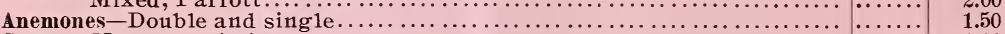

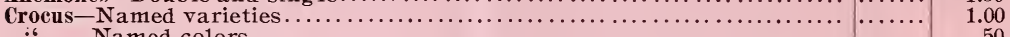

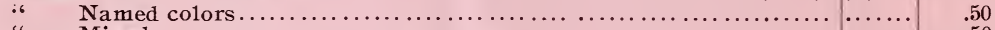

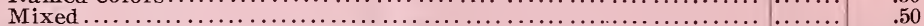

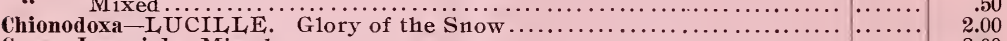

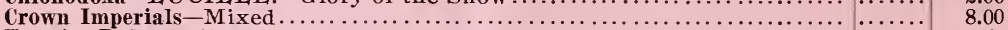

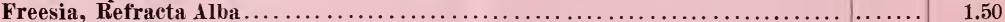

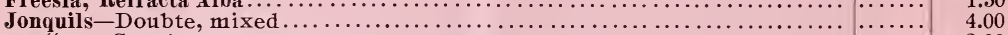

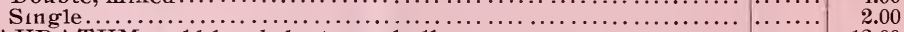

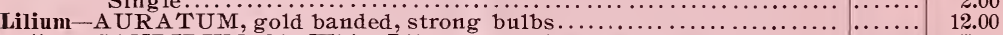

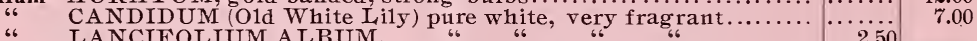

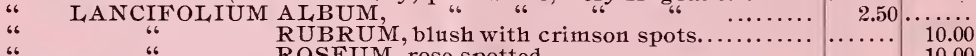

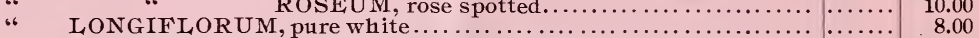

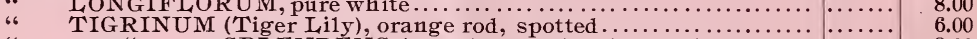

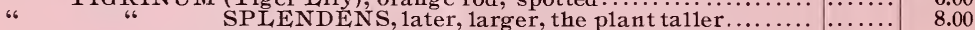

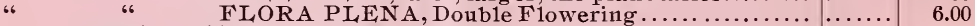

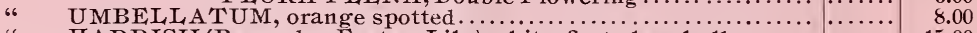

HARRISII (Bermuda . Easter Li1y), white, first-ciass bulbs............. 15.00

Lily of the Valley-CONVALARIA MAJALIS, choice, favorite, ex-

quisite1y fragrant, perfect1y hardy. Pips, per $1,000, \$ 15.00$.

Narcissus-Double and single.

$$
\text { "6 Paper white... }
$$

Oxalis-Mixed

(2.

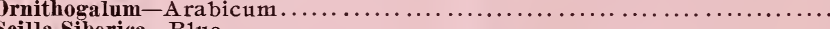

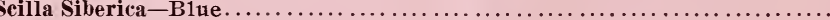

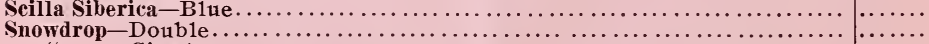

Single.

\subsection{0}

4.00

2.00

8.00

3.50

4.00

1.25

2.50

1.25

\section{GREENHOUSE AND BEDDING PLANTS.}

Prices, except as noted, are for first-class plants of shipping sizes.

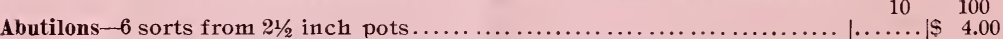

SOUV. DE BONN-Variegated, from $2 \frac{1}{2} \mathrm{inch}$ pots............

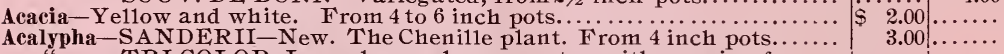

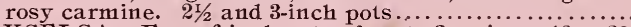

Auracaria-EXCELSA. From 6 -inch pots; four to five tiers; 16 to 20 inches high.

Achyranthus - In variety. From $21 / 2$ inch pots $\ldots$

5.00

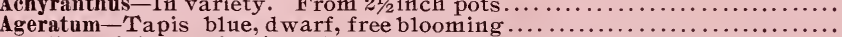

20.00

Princess Pauline-A most distinct and novel variety of dwarf compact habit, rarely exceeding five inches in height, its peculiarity being that both colors, b1ue and white, are combined in the same flower; the body of the flower being white, while the stamens are of a light sky blue, giving the flower a pretty variegated appearance; one of the most distinct new bedding plants that has come under our observation this season. 
F. 99

\section{Phoenix Nursery Company}

\section{BLOOMINGTON,}

Office and Greenhouses:

NORTH PARK STREET, Opp. Wesleyan University,

P. O. Box 625

ILLINOIS. 



\section{Greenhouse and Bedding Plants-Continued.}

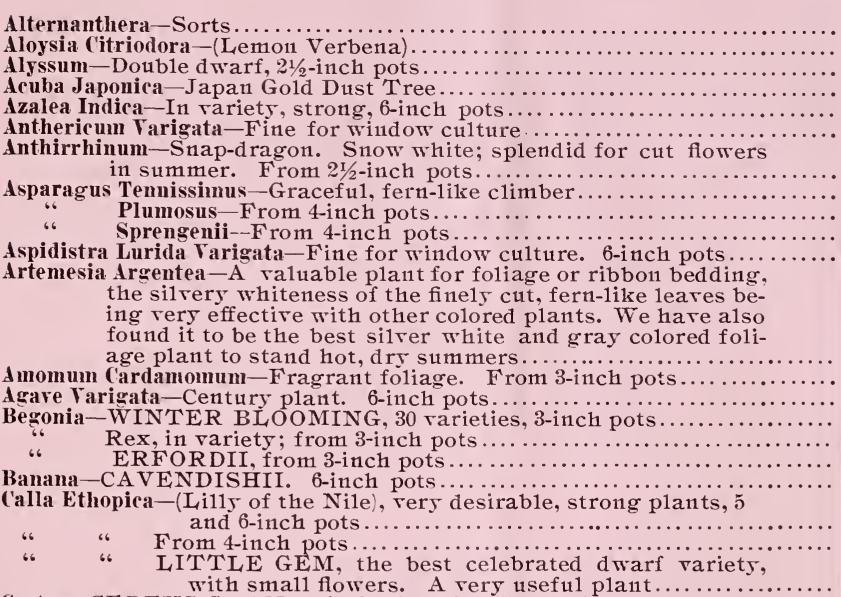

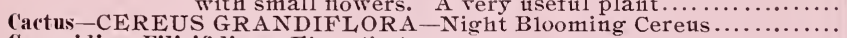
Campsidium Filicifolium-Fine climber.

Cimnamon Vine-DIOSCOREA BATATUS, or Chinese Yam. Good sized roots

Cannas-(See page 22

lants, from open ground. Leading rarieties Begonia Rex

Clerodendron-B A FOURİ $\ddot{H}$ if $\mathrm{c}$. Crimson, the base of each floret surrounded by a white bag1ile calyx ...

Coleus-Choice selection, including set of 1898 , from 2 and $2 \frac{1}{2}-i$ inch pots. Per $1000, \$ 30.00$.

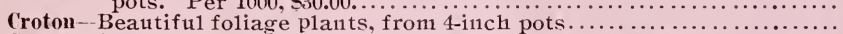
Cyperus Alternifolius-Makes an excellent plant for house decoration

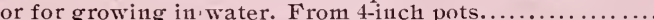

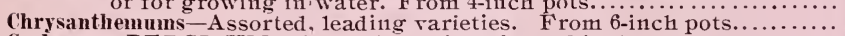

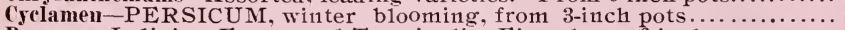

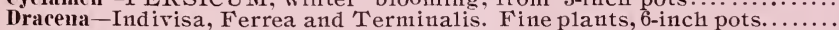
Echeveria-Secunda, Glauca

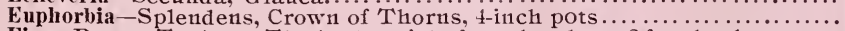
Figs-Brown Turkey-The best rariety for tub culture, 2 feet,bush $5 . . . . .$. Farfugium Grand-LEOPARD PLAN'T. Variegated foliage. From

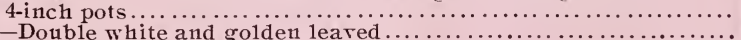
Feverfew-Double white and golden leaved $\ldots \ldots \ldots \ldots \ldots \ldots \ldots \ldots \ldots \ldots \ldots \ldots$

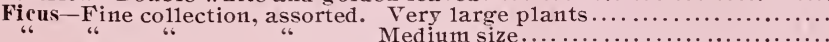
" ELASTICA or RUBBER TREE. From 4 -inch pots $\ldots \ldots \ldots \ldots \ldots \ldots$

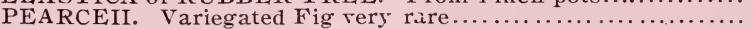

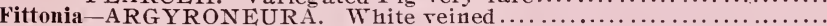

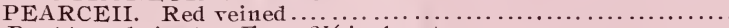

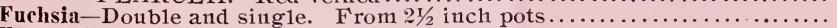
Ferms-A ssorted, in fine variet $y, 4$ inch pots. . . . . . . . . . . . . . . . .

Guava-PSIDIUM CAT'TLEY. Erergreen, with beautifu1 laure1-

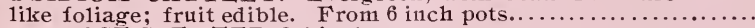

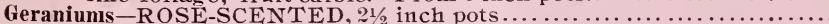

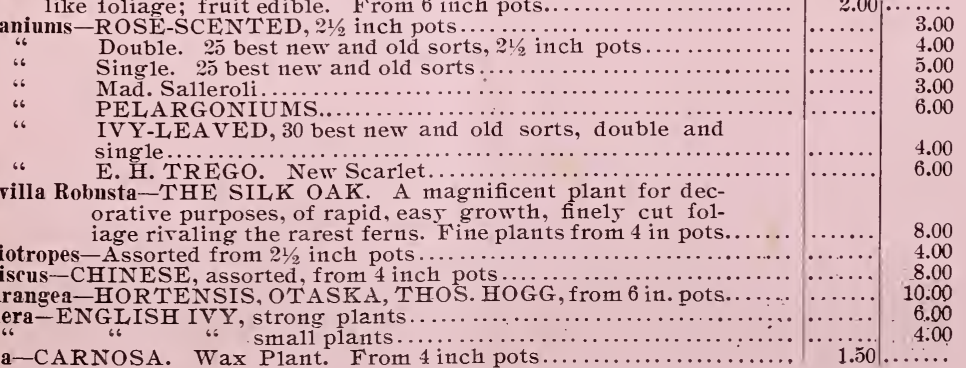




\section{Greenhouse and Bedding Plants-Continued.}

Jasmine-GRAND DUKE, with flowers like sma11 double white roses very fragrant.

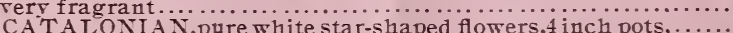

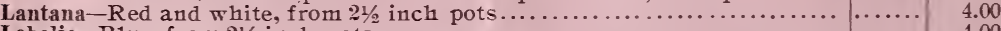

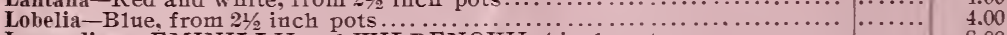

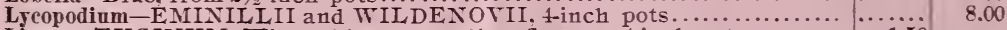

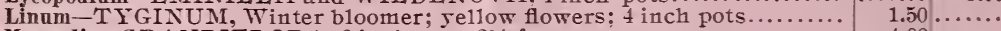

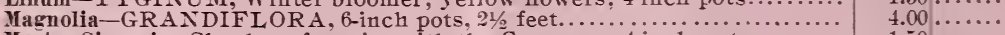

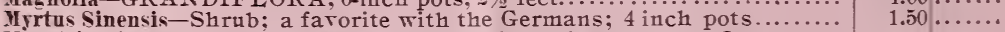

Manettia Bicolor-Rapid growing climber, with bright scarlet flow-

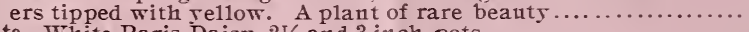

Marguerite-White Paris Daisr, $21 / 2$ and 3 -inch pots..

Myosotis-BLUE BEAUTY. New, larger and brighter than the oidfashioned Forget-me-not...........................................

Orange 0taheite - A dwarf orange, which bears a profusion of frag-

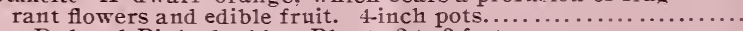

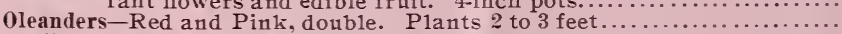
Single. red. white and jellow. From 5 -inch pots............
VARIEGA TA. Finel rariegated white and green foliages, distinct and handsome. Flowers, single, pink..

Palms-ARECA. LUTESCENS, KENTIA. BELMOREANA. CY. CAS REVOLUTA.PHOENIN RECLINATI. LATANIA. BORBONICA. CHAMEROPS EXCELSA. SEAFORTHIA ELEGA NS. Fine plants, from 6 to 8 inch pots, $\$ 1.50$ to $\$ 4.50$ each. We hare larger sizes, prices on application.

ZAMIA. INTEGIFOLIO. Resembling the Crcas. 50c. to $\$ 1.50$ each.

Pansy-From cold frame, fall grown transplanted plants, mixed colors, in bloom after Apri1 1 .

Paser.

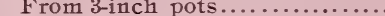

Phlox-See Hardy Herbaceous Plants.

Pyrethrum-See also Herbaceous Plants.

Pelargoniums-See Geraniums.

Peperoma-Metalica. Beautiful house plant. Foliage relrety bronze. 3 -inch pots.

Phryinum Varigatum-Very handsome foliage. Especiaily suitable

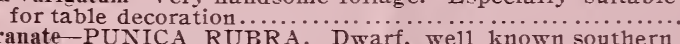

Pommegranate PUNICA RUBRA. Dwarf. weil known southern shrub, fruit edible: vers beautiful when in fruit: 6 inch pots. .

Sanchesia-NOBILIS. Very beautiful rariegated foliage: 4 -inch pots........

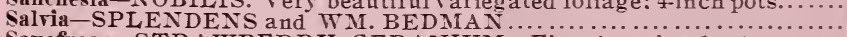

Saxafraga-STRA WBERRY GERANIUM. Fine hanging-basket

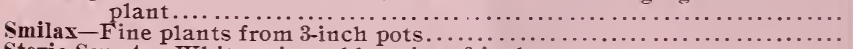

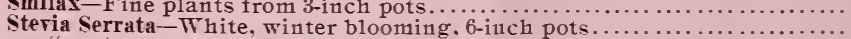
VARIEGATA. White and green foliage. An excellent plant for ribbon bedding. $2 \frac{1}{2}$ inch pots....

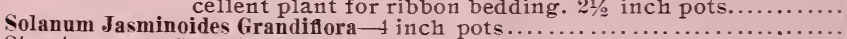

Streptocarpus-CAPE PRIMROSE. New. A very pretty and graceful addition to the Primrose family ..............................

Strobilanthes Dyerianus-A new house and bedding plant. Exquisite-

Swainsonia Galeigfolia Alba-A most desirable winter blooming plant. Flowers pure white. produced in sprays of from 12 to 20

flowers each. From 3 -inch pots $\ldots \ldots \ldots \ldots \ldots \ldots \ldots \ldots \ldots \ldots \ldots \ldots \ldots \ldots \ldots \ldots$
Tritoma-UVARIA GRANDIFLORA (Red Hot Poker) $\ldots \ldots \ldots \ldots \ldots \ldots \ldots$

Valotta Purpurea-A beautiful flowering, bulbous plant, adapted for pot culture, blooming in July and August. Spikes of

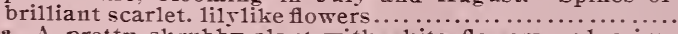

Vinca Alba-A pretty shrubby plant with white flowers and crimson ere. Perpetual summer bloomer.

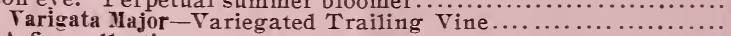

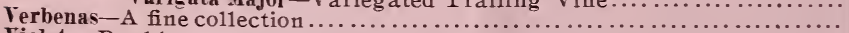

Violets-Double, assorted,

\section{CUT FLOWER DEPARTMENT.}

We respectfully call attention to our Cut'Flower Department. Florists and dealers supplied at lowest Market rates.

\section{BOTQLETS. BASKETS. WREATHS. CROSSES.}

and other designs and Cut Flozvers constantly on hand, arranged and carefully facked on short notice. Prices given on application. Orders by mail or telegraph promptiy executed.

\section{OFFICE OF THE ILLINOIS STATE ENTOMOLOGIST.}

Crbana. III.. August 29. 1899.

This is to certify that the growing nursery stock and premises of the Phoenix Nursery Company, situated at Bloomington. Ill.. hare been inspected according to the provisions of an Act to prevent the introduction and spread in Illinois of the San Jose scale and other dangerous insects and contagious diseases of fruits. approved and in force $A$ pril 11. 1899. and that no in. dications have been found of the presence of the San Jose scale or other dangerous insect or plant disease.

This certificate is invalid after June 1, 1900.

S. A. FORBES, State Entomologist. 